\title{
Richness, diversity patterns, and taxonomic notes of amphibians from the Tocantins state
}

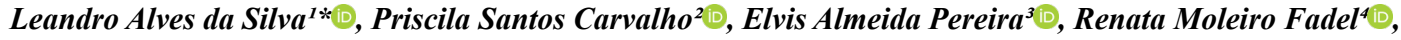

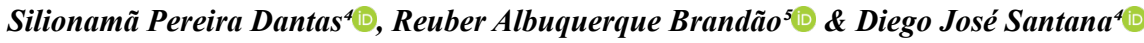 \\ ${ }^{1}$ Universidade Federal da Paraíba, Pós-Graduação em Ciências Biológicas - Concentração em Zoologia, \\ João Pessoa, PB, Brasil \\ ${ }^{2}$ Universidade Estadual Paulista, Programa de Pós-Graduação em Biologia Animal, São José do Rio Preto, SP, Brasil \\ ${ }^{3}$ Universidade Federal Rural do Rio de Janeiro, Departamento de Biologia Animal, Laboratório de Herpetologia, \\ Seropédica, RJ, Brasil \\ ${ }^{4}$ Universidade Federal de Mato Grosso do Sul, Instituto de Biociências, Laboratório de Zoologia, Campo Grande, \\ MS, Brasil \\ ${ }^{5}$ Universidade de Brasilia, Departamento de Engenharia Florestal, Laboratório de Fauna e Unidades de Conservação, \\ Brasília, DF, Brasil \\ *Corresponding author: Leandro Alves da Silva, e-mail: leandroherpeto@gmail.com \\ SILVA, L.A., CARVALHO, P.S., PEREIRA, E.A., FADEL, R.M., DANTAS, S.P., BRANDÃO, R.A., SANTANA, \\ D.J. Richness, diversity patterns, and taxonomic notes of amphibians from the Tocantins state. Biota \\ Neotropica. 20(1): e20190838. http://dx.doi.org/10.1590/1676-0611-BN-2019-0838
}

\begin{abstract}
Herein, we provide the first comprehensive amphibian checklist for the State of Tocantins, North of Brazil, based on field sampling, literature data, and specimens deposited in zoological collections. We performed field surveys from 2012 to 2019 in 12 Tocantins municipalities, totaling 376 days of sampling effort. We analyzed 25 papers from the literature and examined 1311 specimens from collections and collected 750 during field surveys. We recorded 90 amphibian species distributed in 12 anurans and two caecilians families. At least seven undescribed species along the state were recorded. We also present new records for 20 species for the state, nine of them corresponding to Amazonian species, four Cerrado endemic, one Caatinga species, and the widely distributed treefrog Boana crepitans; the others five new records comprise undescribed species. Our data also suggest that the Tocantins amphibian composition is not geographically structured in relation to the biomes, since Amazonian, Caatinga, and Cerrado amphibian lineages have their distribution nearly completely overlapped in the state. We propose that this absence of spatial structuration may be a result of two factors (synergetic or not). First, the events of expansion and retraction of the biomes caused by the Quaternary climatic cycles, which may have mixed the populations of species from different biomes causing the notable pattern of overlapped distribution observed here. Second, the forest environments (e.g. gallery and riparian forests) associated to the Araguaia-Tocantins River basins may have acted as historical dispersal corridors for the Amazonian amphibian lineages into the Cerrado of the Tocantins. Despite the sampling effort of the present study, we stress that gaps of information still remain and further field sampling efforts should be performed along the state. Lastly, taxonomic appraisals involving the species with problematic taxonomic status recorded here should be based on multiples lines of evidences (acoustic, molecular, and morphological data), which will render a more accurate view on the Tocantins amphibian diversity. Such data are extremely necessary under the current high rate of habitat loss across the state, since they can be used to guide public policies of conservation.
\end{abstract}

Keywords: Amazonian Forest, Amphibia, Savanna, Cerrado.

\section{Riqueza, padrões de diversidade e notas taxonômicas dos anfíbios do estado do Tocantins}

Resumo: Apresentamos aqui a primeira lista de anfíbios para o estado do Tocantins, região norte do Brasil, com base em amostragens de campo, dados da literatura e espécimes depositados em coleções zoológicas. As expedições de campo foram realizadas entre 2012 e 2019 em 12 municípios do Tocantins, totalizando 376 dias de esforço amostral. Nós analisamos 25 artigos da literatura, examinamos 1311 espécimes depositados em coleções e coletamos 750 indivíduos durante as amostragens de campo. No total, nós registramos 90 espécies de anfíbios distribuídas em 14 famílias, das quais 12 são de anuros e duas são de gimnofionas. Nossas amostragens também indicam a presença de ao menos sete espécies não descritas ao longo do estado. Adicionalmente, fornecemos registros inéditos para 20 espécies, das quais nove são amazônicas, quatro são endêmicas do Cerrado, uma espécie da Caatinga e uma amplamente distribuída, a perereca Boana crepitans; cinco das espécies cujos os registros são inéditos para o estado correspondem a linhagens 
não descritas. Nossos dados também sugerem que a fauna de anfíbios do Tocantins não está geograficamente estruturada em relação aos biomas, uma vez que linhagens de anfíbios amazônicos, da Caatinga e endêmicas do Cerrado apresentaram distribuição quase completamente sobreposta ao longo de todo o estado. Nós propomos que essa ausência de estruturação espacial pode ser o resultado de dois fatores (sinergéticos ou não). Primeiro, os eventos de expansão e retração dos biomas causados pelos ciclos climáticos do quaternário, que podem ter mixado as populações de espécies de diferentes biomas, promovendo o padrão de sobreposição de distribuição geográfica aqui observado. Segundo, destacamos que os ambientes florestais (e.g. matas de galeria e ripárias) associadas às bacias do dos Rios Araguaia-Tocantins podem ter atuado como corredores históricos de dispersão para linhagens de anfíbios amazônicos para dentro do Cerrado tocantinense. A despeito do esforço de amostragem do presente estudo, lacunas de informação em diversas áreas do estado permanecem e apontam a necessidade de adicionais amostragens de campo. Além disso, diversas espécies com status taxonômico problemático foram diagnosticadas no presente estudo, e futuras avaliações das mesmas devem ser baseadas em múltiplas linhas de evidência (dados acústicos, moleculares e morfológicos), produzindo assim uma visão mais acurada sobre a diversidade de anfíbios do estado do Tocantins. Essas informações são extremamente necessárias em vista das atuais taxas de degradação ambiental dentro do estado do Tocantins, uma vez que esse tipo de informação pode auxiliar políticas públicas voltadas para conservação.

Palavras-chave: Floresta Amazônica, Amphibia, Savana, Cerrado.

\section{Introduction}

Political boundaries rarely coincide with natural barriers for animal and plant distributions. However, accurate biodiversity data for geopolitical units directly influences conservation policies (Diniz-Filho et al. 2005, Silveira et al. 2010, Roberto \& Loebmann 2016). A crucial step in determining biodiversity conservation actions is the production of basic information about diversity, distribution, and natural history of the target group (Bini et al. 2006, Toledo et al. 2014). In fact, under the current high rate of anthropogenic changes, these data are extremely necessary (Vitousek et al. 1997, Hoffman et al. 2010, McCallum 2015). This is especially true for amphibians, one of the most threatened vertebrate group in the world (Silvano \& Segalla 2005, Gallant et al. 2007, Hoffman et al. 2010).

Brazil holds the most diverse amphibian fauna of the world (Segalla et al. 2019). Nevertheless, few Brazilian states have comprehensive amphibian checklists (e.g. Almeida et al. 2011, Rossa-Feres et al. 2011, Roberto et al. 2013, Almeida et al. 2016, Brandão et al. 2016, Roberto \& Loebmann 2016). The paucity of such studies is mainly due to the i) large size of the states, which makes samplings efforts logistically difficult, and ii) the lack of human resources to produce these checklists. To overcome this shortfall, large inventories have often used a compilation of information from different sources as literature data, specimens deposited in zoological collections, and field samplings (e.g. Almeida et al. 2011, Rossa-Feres et al. 2011, Roberto et al. 2013, Almeida et al. 2016).

Despite its large territory and by the presence of several ecosystems within its boundaries, the amphibian diversity of the state of Tocantins is poorly known (Diniz-Filho et al. 2005, 2006). Located on the central portion of Brazil, the Cerrado biome covers $92 \%$ of the state, encompassing many phytophysiognomies, from savanna formations (e.g. Cerrado stricto sensu) to forest environments (e.g. gallery forest) (OliveiraFilho \& Ratter 2002, Sano et al. 2010), placed side by side along the landscape. This habitat distribution promotes a natural fragmentation of the landscape, which deeply influences the amphibian occupancy and diversity of the Cerrado biome (Colli et al. 2002, Santoro \& Brandão 2014).
Despite the increase of anthropogenic pressures on the Cerrado in past decades, Tocantins still presents large natural areas of Cerrado, with nearly $79 \%$ of its typical habitats poorly altered by human activities (Santos et al. 2007, Sano et al. 2010, Rocha et al. 2011, Françoso et al. 2015). Additionally, two other South American biomes are present in the Tocantins, the Amazonia and enclaves of the Seasonally Dry Tropical Forests (SDTFs) (Werneck 2011, Tocantins 2015). The Amazonia biome is present in the northwest portion of the state, covering nearly $7 \%$ of its territory, with additional extensive transitional zones between them and the Cerrado in the west of the state. The enclaves of SDTFs (commonly referred as Matas secas) presents in the southern and eastern portions of Tocantins share close evolutionary history with the Caatinga (Werneck 2011). The SDTFs formations are adapted to the severe drought conditions, and one of its main attributes is the loss of leaves during the dry season (Araújo et al. 2007). Thus, several amphibian lineages from the Amazonia, Cerrado and SDTFs can be found in the Tocantins (Brandão \& Peres Jr 2001, Pavan 2007, Brasileiro et al. 2008, Valdujo et al. 2011, 2012, Silva et al. 2014, 2018). In this context, comprehensive inventories can also greatly improve our understanding about the biogeography and evolution of the amphibians of the study area (Silvano \& Segalla 2005, Valdujo et al. 2012, Roberto \& Loebmann 2016).

Despite the current deficit of sampling effort regard the Tocantins amphibian fauna, some regions of the state were recovered as endemism centers and/or priority areas for herpetofauna conservation, as the Paranã Valley and Tocantins-Araguaia River basins (Azevedo et al. 2016). This highlight the necessity to improve our knowledge about the amphibians of the State of Tocantins. Herein, we provide the first comprehensive amphibian checklist for Tocantins state based on field sampling, literature data, and specimens deposited in zoological collections. In addition, we also $i$ ) address the geographic patterns of the amphibian diversity analyzing the spatial distribution of species with different ranges (i.e. Cerrado endemic, Amazonian, and Caatinga species), ii) identify gaps on geographic and taxonomic knowledge, suggesting priority areas and taxa for further studies, and iii) provide taxonomic notes to some recorded species. 


\section{Material and Methods}

\section{Study area}

The Tocantins is the third larger state of the north of Brazil, with nearly $278,000 \mathrm{~km}^{2}$ (Figure 1). The Cerrado biome vegetation cover most of the state, but the Amazonia Forest and few enclaves of SDTFs are also present (Sano et al. 2010, Werneck 2011). The regional precipitation varies between 1,300 and $1,900 \mathrm{~mm}$ per year, generally concentrated between December and March, the climate is tropical, with a dry winter and moist summer (AW), according to Köppen classification; mean temperature annual near to $32{ }^{\circ} \mathrm{C}$ (Alvares et al. 2013a, b). The main plateaus are present in the center (e.g. Parque Estadual do Lajeado), south (e.g. Serra das Traíras) and east (e.g. Serra
Geral) of the state. Lowlands are mainly located along the two major hydrographic basins of the state, the Araguaia and Tocantins Rivers. The Araguaia River is located at the western limit of the state (borderline with Mato Grosso in Midwest to South and Pará in Midwest and North), while the Tocantins River is centrally located, crossing the state in a south-north orientation. Additionally, the state is the newest federative unity of the Brazil, created in 1989. The main center of research of the state is the Universidade Federal do Tocantins (UFT), which was created just in 2000 and currently have seven campi spread throughout the state (UFT 2018). This university offer the bachelor degree in Biological Sciences only in the municipality of Porto Nacional. Even nowadays, no amphibian's specialist works in any campi of the UFT. The large state territory and the absence of local researchers are the main reasons to the current scarcity of information on the Tocantins amphibian community.

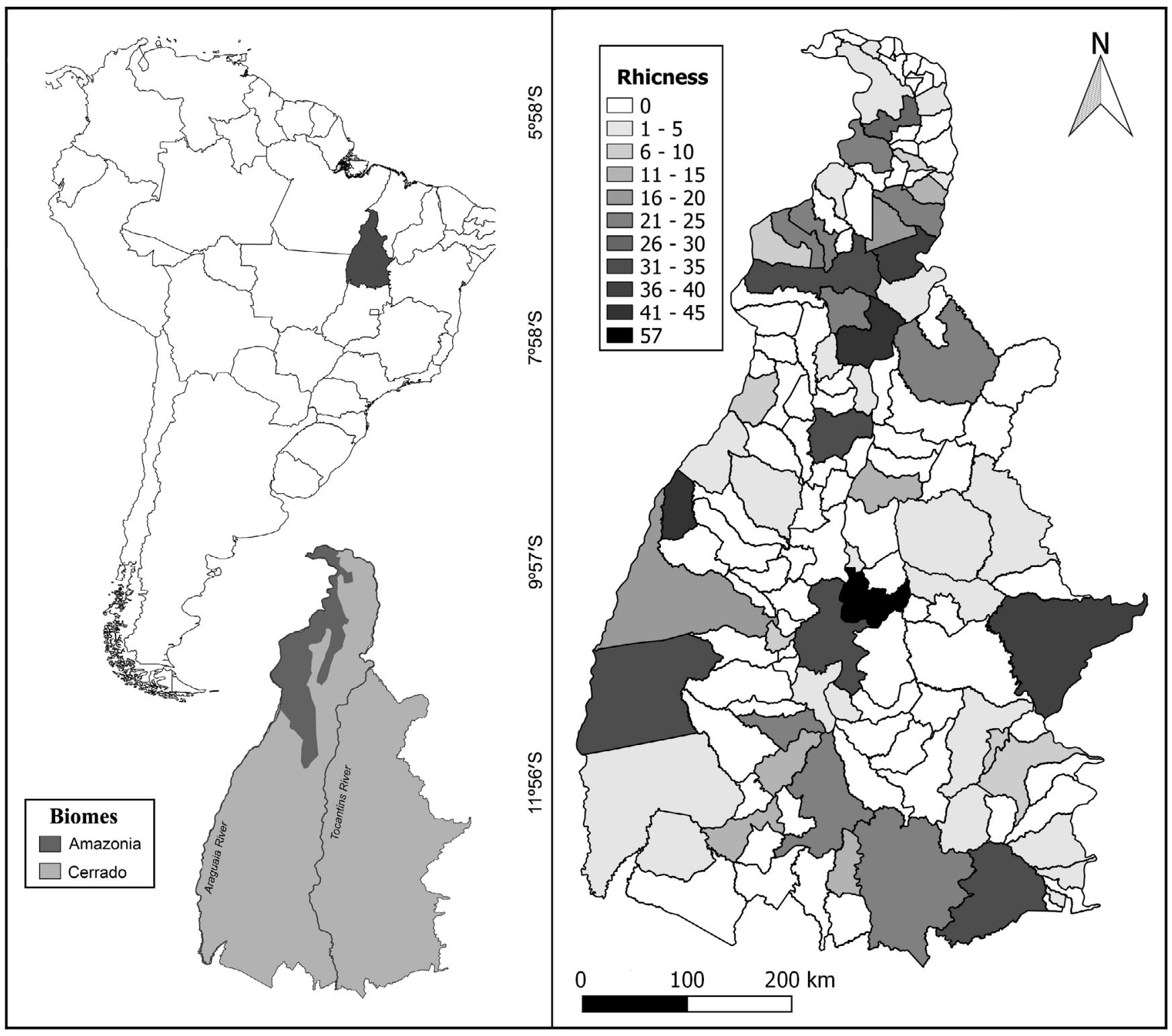

Figure 1. Biomes, River basins, and Richness of amphibian species by municipalities in the State of Tocantins. 


\section{Sampling}

Our amphibian checklist is result of a compilation of literature data, specimens deposited in zoological collections, and field samplings. The literature data was obtained by $i$ ) searching the international databases (Web of Science, Scielo and Scopus) using the follow key-word combinations: Amphibia*Cerrado or Anura*Cerrado or Herpetofauna*Cerrado or Amphibia*Savanna*Brazil or Anura*Savanna*Brazil or Herpetofauna*Savanna*Brazil. Searches in the mentioned bases with key-words referring to Amazonian biome (e.g. Amphibian*Amazonia*Tocantins) returned only two articles, which just one (of our authorship, Andrade et al. 2019) fits to our study aim. Thus, include these words do not improved the literature dataset. That's maybe a result of the smaller spatial representativity of the Amazonian biome within the state and the absence of the researcher groups in the region; and ii) searching papers from personal libraries not found in the above-mentioned databases. We started gathering papers from international databases in April of 2015, without start date restriction. To avoid artificial richness inflation of the species list, we used two exclusion criteria for literature records: $i$ ) species identified with some taxonomic indetermination (i.e. aff., cf., gr. and sp.), and ii) inaccuracy in determination of the sampled area. When applicable, we updated the nomenclature of some records and/or corrected identifications based on newly published information.

We directly analyzed specimens in four zoological collections: Laboratório de Caracterização de Impactos Ambientais (acronym LCIA), from the Universidade Federal do Tocantins, campus Palmas, Tocantins; Museu de Zoologia José Hidasi (acronym MZJH), Porto Nacional municipality, Tocantins; Coleção Herpetológica da Universidade de Brasília (acronym CHUNB), Brasília municipality, Distrito Federal; and Museu Nacional do Rio de Janeiro (acronym MNRJ),
Rio de Janeiro municipality, Rio de Janeiro. We also measured and photographed specimens of some species to allow comparisons of records from different collections and/or field samplings (Appendix 1).

We performed field surveys from 2012 to 2019 in 12 Tocantins municipalities, totaling 376 days of sampling effort (Table 1). We used at least one of the following three methods in the sampling areas: visual search, pitfall traps, and incidental records. When possible, advertisement calls were also recorded to help species identification. The collected specimens were killed by immersion in benzocaine hydrochloride $250 \mathrm{mg} / \mathrm{l}$ or interpectoral injection of lidocaine (CFBio $\mathrm{n}^{\circ}$ 148/2012), fixed in $10 \%$ formalin solution, and permanently preserved in $70 \%$ alcohol. Before fixation, we extracted tissue samples (liver or muscle) and preserved them in alcohol $95 \%$. All collected specimens and tissue samples are housed in the amphibians collection of the Coleção Zoológica da Universidade Federal de Mato Grosso do Sul (acronym ZUFMS-AMP). The Instituto Chico Mendes de Biodiversidade (acronym ICMBio) granted the collection permits (51036-2 and 54493-11).

\section{Data analysis}

Some lineages are hard to be identified at specific level based only on morphological characters, as Adenomera, Pseudopaludicola, and Pristimantis genera (Carvalho \& Giaretta 2013, Padial et al. 2014, Veiga-Menoncello et al. 2014, Carvalho et al. 2015a, b, Andrade et al. 2016, 2017). Therefore, specimens of these groups collected or analyzed in zoological collections without specific identification were excluded from the list, except when we were able to distinguish them from their already registered congeners. Despite excluding some of these records from the list, we maintained them to analyze the richness by municipality, except when morphologically similar congeners were also reported for the same municipality.

Table 1. Sampled areas in the State of Tocantins. Biome: Cerrado, Ecotone - Transitional areas between Amazonian and Cerrado. Environment - AT: anthropic (e.g. pastures), forest formation (e.g. gallery forest), OA: open areas (e.g. cerrado stricto sensu). Water body sampled - P: ponds, R: river, S: streams. Methods - OE: occasional encounter, PT: pitfalls, VS: visual surveys. The richness presented here is the compilation of records obtained from field sampling, literature, and zoological collections. The richness corresponds to the total of records (sum of field surveys, literature, and zoological collections data) from each municipality.

\begin{tabular}{|c|c|c|c|c|c|c|c|c|c|}
\hline $\begin{array}{l}\text { Sampling } \\
\text { effort }\end{array}$ & Municipality & Biome & Richness & Environment & $\begin{array}{l}\text { Water } \\
\text { body }\end{array}$ & Methods & Period & Lat. & Long. \\
\hline 80 days & Araguaína & Ecotone & 35 & AT, FF & $\mathrm{P}, \mathrm{S}$ & OE,PT,VS & $2013-2016$ & $7^{\circ} 06^{\prime} 15^{\prime \prime S}$ & $48^{\circ} 12^{\prime} 00^{\prime \prime} \mathrm{W}$ \\
\hline 30 days & Arraias & Cerrado & 33 & OA, AT & $\mathrm{S}$ & OE,PT,VS & 2016-2019 & $12^{\circ} 55^{\prime} 50^{\prime \prime} \mathrm{S}$ & $46^{\circ} 56^{\prime} 42^{\prime \prime} \mathrm{W}$ \\
\hline 52 days & Caseara & Ecotone & 42 & $\mathrm{OA}, \mathrm{AT}, \mathrm{FF}$ & $\mathrm{P}, \mathrm{R}, \mathrm{S}$ & OE,PT,VS & 2017-2018 & $9^{\circ} 24^{\prime} 17^{\prime \prime} \mathrm{S}$ & $49^{\circ} 58^{\prime} 59^{\prime \prime} \mathrm{W}$ \\
\hline 3 days & $\begin{array}{l}\text { Colinas do } \\
\text { Tocantins }\end{array}$ & Ecotone & 4 & AT, FF & $\mathrm{P}$ & VS & $10 / 2016$ & $8^{\circ} 3^{\prime} 28^{\prime \prime} \mathrm{S}$ & $48^{\circ} 28^{\prime} 34^{\prime \prime} \mathrm{W}$ \\
\hline 3 days & $\begin{array}{l}\text { Couto de } \\
\text { Magalhães }\end{array}$ & Ecotone & 7 & $\mathrm{OA}, \mathrm{AT}$ & $\mathrm{P}$ & VS & $10 / 2016$ & $8^{\circ} 17^{\prime} 22^{\prime \prime} \mathrm{S}$ & $49^{\circ} 14^{\prime} 53^{\prime \prime} \mathrm{W}$ \\
\hline 10 days & Figueirópolis & Ecotone & 13 & $\mathrm{OA}, \mathrm{AT}, \mathrm{FF}$ & $\mathrm{P}$ & OE,PT,VS & $10 / 2015$ & $12^{\circ} 07^{\prime} 51^{\prime \prime} \mathrm{S}$ & $49^{\circ} 10^{\prime} 26^{\prime \prime} \mathrm{W}$ \\
\hline 10 days & Gurupi & Cerrado & 12 & OA, AT & $\mathrm{P}$ & OE,PT,VS & $10 / 2015$ & $11^{\circ} 43^{\prime} 44^{\prime \prime} \mathrm{S}$ & $49^{\circ} 04^{\prime} 08^{\prime \prime} \mathrm{W}$ \\
\hline 22 days & $\begin{array}{l}\text { Lagoa da } \\
\text { Confusão }\end{array}$ & Ecotone & 34 & $\mathrm{OA}, \mathrm{AT}, \mathrm{FF}$ & $\mathrm{P}, \mathrm{R}$ & OE,PT,VS & $10 / 2015$ & $10^{\circ} 48^{\prime} 44^{\prime \prime} \mathrm{S}$ & $49^{\circ} 54^{\prime} 51^{\prime \prime} \mathrm{W}$ \\
\hline 9 days & Mateiros & Cerrado & 40 & $\mathrm{OA}, \mathrm{AT}$ & $\mathrm{P}, \mathrm{R}, \mathrm{S}$ & OE,PT,VS & $03 / 2018$ & $10^{\circ} 33^{\prime} 45^{\prime \prime} \mathrm{S}$ & $46^{\circ} 13^{\prime} 12^{\prime \prime} \mathrm{W}$ \\
\hline 144 days & Palmas & Cerrado & 57 & $\mathrm{FF}$ & $\mathrm{P}, \mathrm{S}$ & OE,PT,VS & 2012-2018 & $10^{\circ} 17^{\prime} 47^{\prime \prime} \mathrm{S}$ & $48^{\circ} 07^{\prime} 42^{\prime \prime} \mathrm{W}$ \\
\hline 3 days & Palmeirante & Ecotone & 41 & $\mathrm{OA}, \mathrm{AT}$ & $\mathrm{P}$ & VS & $10 / 2016$ & $7^{\circ} 51^{\prime} 44^{\prime \prime} \mathrm{S}$ & $47^{\circ} 56^{\prime} 9^{\prime \prime} \mathrm{W}$ \\
\hline 10 days & Porto Nacional & Cerrado & 34 & AT, FF & $\mathrm{P}, \mathrm{R}, \mathrm{S}$ & OE,PT,VS & $10 / 2015$ & $10^{\circ} 42^{\prime} 28^{\prime \prime} \mathrm{S}$ & $48^{\circ} 25^{\prime} 01^{\prime \prime} \mathrm{W}$ \\
\hline
\end{tabular}


We follow Valdujo et al. (2012) to determine the distribution pattern of the registered species. Here, the categories are briefly described as EN: Cerrado endemic species, for species exclusively found through Cerrado; AM: Amazonian species, when their range comprise the Amazonia and marginal zones of the Cerrado; CA: Caatinga species, when their range comprise the Caatinga and marginal zones of the Cerrado; BD: species found throughout South American open formations (SDTFs, Cerrado, and Chaco); and WD: widely distributed species, when their range encompass more the two biomes (except BD species) (see Valdujo et al. 2012 for more details about these distribution categories). Also following Valdujo et al. (2012), we plotted in a map all records of each species distribution category and observed if them were structured through the state or not. Based on the field surveys and literature data, we also associated each species to different environments: AT - anthropic, as pastures; FF - forest formation, as gallery forest; and $\mathrm{OA}$ - open areas, as Cerrado stricto sensu. The water bodies explored for each species were classified as pond, stream, and river.

\section{Results}

\section{Richness}

We analyzed 25 works from literature, collected 750 specimens during 376 days field surveys and examined 1311 specimens from collections (totaling 2.061 specimens). We recorded 90 amphibian species distributed in 14 families, 12 anuran families and two caecilians families (Table 2; Figures 2-7, Appendix 1). The most representative families were Hylidae (33 spp.) and Leptodactylidae (30 spp.). The richness presented by each source was very similar, as we found 75 spp. during field samplings, 72 spp. through literature data, and 63 spp. from zoological collections. On the other hand, many records were performed exclusively by one of the sources, as 11 species were registered solely during field samplings, seven species only from the literature data, and five only from zoological collections data (Table 2). We recovered 56 municipalities with some information about amphibians,

Table 2. Diversity and distribution of the amphibians species in the State of Tocantins. Abbreviations - Municipalities: $A A=A r a g u a c e m a, A G=$ Aragominas, $\mathrm{AI}=$ Aguiarnópolis, $\mathrm{AL}=$ Aliança do Tocantins, $\mathrm{AM}=\mathrm{Almas}, \mathrm{AN}=$ Ananás, $\mathrm{AR}=$ Araguaína $, \mathrm{AS}=\mathrm{Arraias}, \mathrm{AT}=\mathrm{Araguatins}, \mathrm{AU}=$ Aurora do Tocantins, $\mathrm{BA}=$ Babaçulândia, $\mathrm{BN}=$ Brejinho de Nazaré, $\mathrm{BT}=$ Buriti do Tocantins, $\mathrm{CA}=\mathrm{Caseara}, \mathrm{CB}=\mathrm{Combinado}, \mathrm{CM}=\mathrm{Couto}$ de Magalhães, $\mathrm{CO}=$ Colinas do Tocantins, $\mathrm{CT}=$ Conceição do Tocantins, $\mathrm{DA}=$ Darcinópolis, $\mathrm{DI}=$ Dianópolis, $\mathrm{DO}=\mathrm{Dois}$ Irmãos do Tocantins, $\mathrm{FA}=$ Formoso do Araguaia, FI = Figueirópolis, FL = Filadélfia, GA = Guaraí, GO = Goiatins, GU = Gurupi, IP = Ipueiras, IT = Itaguatins, LA = Lajeado, $\mathrm{LG}=$ Lagoa da Confusão, $\mathrm{LZ}=$ Lizarda, $\mathrm{MA}=$ Mateiros, $\mathrm{MU}=$ Muricilândia, $\mathrm{NA}=$ Nazaré, $\mathrm{NO}=$ Nova Olinda, $\mathrm{NR}=\mathrm{Nova}$ Rosalândia, $\mathrm{NV}=$ Novo Acordo, $\mathrm{PA}=$ Palmas, $\mathrm{PE}=$ Pedro Afonso, $\mathrm{PI}=$ Pium, $\mathrm{PL}=$ Palmeirante, $\mathrm{PM}=$ Palmeiras do Tocantins, $\mathrm{PR}=\mathrm{Paranã}, \mathrm{PO}=\mathrm{Porto}$ Nacional, $\mathrm{PT}$ $=$ Porto Alegre do Tocantins, $\mathrm{PX}=$ Peixe, RS = Rio Sono, $\mathrm{SA}=$ São Bento do Tocantins, $\mathrm{SF}=$ Santa Fé do Araguaia, $\mathrm{SN}=\mathrm{Sandolândia,} \mathrm{SS}=\mathrm{São}$ Salvador do Tocantins, TA = Taguatinga, TU = Tupiratins, WA = Wanderlândia, XA = Xambioá. Vegetation: AT = anthropic (e.g. pasturelands), FF $=$ forest formation (e.g. gallery forest, "cerradão"), $\mathrm{OA}=$ open areas (e.g. grassland, cerrado stricto sensu). Water body: $\mathrm{Ri}=$ river, $\mathrm{Po}=\mathrm{Ponds}, \mathrm{St}=$ stream. Range: $\mathrm{AM}=$ Amazonian species that reach the Cerrado biome, $\mathrm{AT}=$ Atlantic species that reach the Cerrado biome, $\mathrm{DB}=\mathrm{South}$ American diagonal belt of open formations, $\mathrm{CA}=$ Caatinga species that reach the Cerrado biome, $\mathrm{CHA}=\mathrm{Chaco}$ species that reach the Cerrado biome, EN $=$ Cerrado endemic, WD = Widespread are those occur in two or more biomes, except DB ones. Conservation Units (UCs): APA = Área de Proteção Ambiental Serra do Lajeado; PEC: Parque Estadual do Cantão; PEJ: Parque Estadual do Jalapão. IUCN status: DD = Data deficient, LC = Least concern, $\mathrm{NE}=$ Not evaluated species. Record: $\mathrm{FS}=$ Field sampling, $\mathrm{LI}=$ Literature, $\mathrm{ZC}=$ Zoological collections. New records are indicated by an asterisk.

\begin{tabular}{|c|c|c|c|c|c|c|c|}
\hline Taxa & Municipalities & Vegetation & Water body & Range & UCs & IUCN & Record \\
\hline Aromobatidae & - & - & - & - & - & - & - \\
\hline $\begin{array}{l}\text { Allobates crombiei } \\
\text { (Morales, 2002) * }\end{array}$ & $\begin{array}{c}\text { AR,CA,GA,LA, } \\
\text { PA,SA,XA }\end{array}$ & $\mathrm{FF}$ & St & $\mathrm{AM}$ & APA & $\mathrm{DD}$ & FS,LT, ZC \\
\hline Bufonidae & - & - & - & - & - & - & - \\
\hline $\begin{array}{l}\text { Rhaebo guttatus } \\
\text { (Schneider, 1799) }\end{array}$ & $\begin{array}{l}\text { AN,AR,CA,CM, } \\
\text { DI,GA,MA,MU, } \\
\text { SA,TU,XA }\end{array}$ & $\mathrm{FF}$ & $\mathrm{Ri}, \mathrm{St}$ & $\mathrm{AM}$ & PEC,PEJ & $\mathrm{LC}$ & FS,LT, ZC \\
\hline Rhinella diptycha (Cope, 1862) & $\begin{array}{c}\text { AA,AG,AL,AR, } \\
\text { AS,BA,CA,DA, } \\
\text { DI,FI,GA,LG,MA, } \\
\text { MU,NO,NR,PA,PI, } \\
\text { PL,PO,PR,PX,SA,SS }\end{array}$ & $\mathrm{AT}, \mathrm{FF}, \mathrm{OA}$ & $\mathrm{Po}, \mathrm{St}$ & WD & $\begin{array}{l}\text { APA,PEC, } \\
\text { PEJ }\end{array}$ & $\mathrm{DD}$ & FS,LT, ZC \\
\hline $\begin{array}{l}\text { Rhinella mirandaribeiroi } \\
\text { (Gallardo, 1965) }\end{array}$ & $\begin{array}{c}\text { AR,AS,AT,BA,BN, } \\
\text { CA,CO,DA,GA,GO, } \\
\text { GU,IP,LG,MA,MU, } \\
\text { NO,NR,PA,PO,PT, } \\
\text { SA,SF,SS }\end{array}$ & $\mathrm{AT}, \mathrm{FF}, \mathrm{OA}$ & Po,St & EN & APA,PEJ & $\mathrm{NE}$ & FS,LT, ZC \\
\hline
\end{tabular}


Silva, LA. et al.

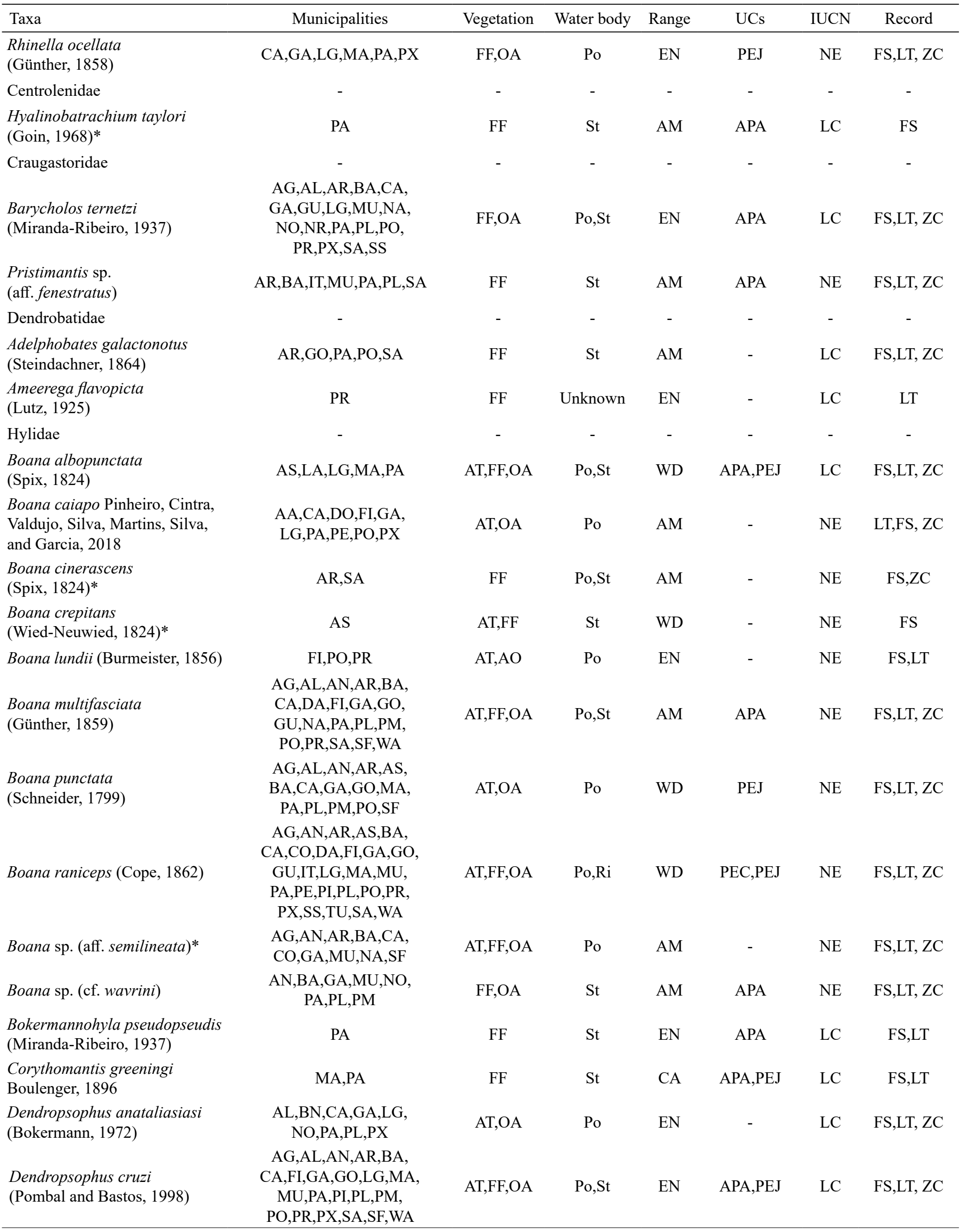




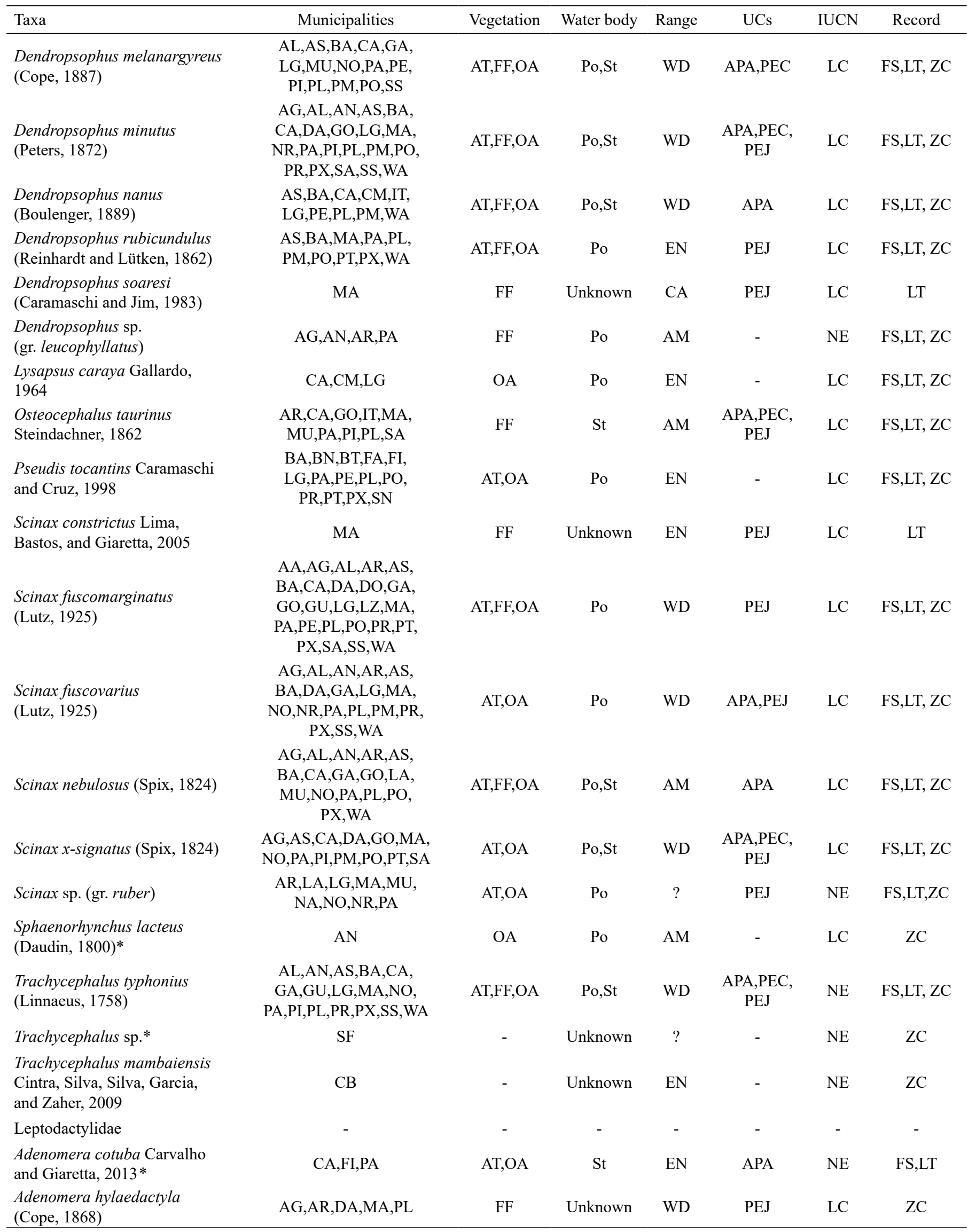




\begin{tabular}{|c|c|c|c|c|c|c|c|}
\hline Taxa & Municipalities & Vegetation & Water body & Range & UCs & IUCN & Record \\
\hline $\begin{array}{l}\text { Adenomera juikitan } \\
\text { Steindachner, } 1867^{*}\end{array}$ & $\mathrm{CA}, \mathrm{PA}, \mathrm{SA}$ & AT,OA & St & EN & APA & NE & FS \\
\hline $\begin{array}{l}\text { Adenomera saci Carvalho and } \\
\text { Giaretta, } 2013\end{array}$ & $\begin{array}{l}\text { AM,CA,FA,GA,LG, } \\
\text { MA,MU,PA,PL,PX }\end{array}$ & OA & St & $\mathrm{EN}$ & PEJ & NE & $\mathrm{FS}, \mathrm{LT}, \mathrm{ZC}$ \\
\hline Adenomera sp. $1^{*}$ & $\mathrm{CA}, \mathrm{SA}$ & AT,OA & $\mathrm{St}$ & $?$ & - & $\mathrm{NE}$ & FS \\
\hline Adenomera sp. $2^{*}$ & $\mathrm{AR}$ & $\mathrm{FF}$ & St & $?$ & - & $\mathrm{NE}$ & FS \\
\hline $\begin{array}{l}\text { Leptodactylus furnarius } \\
\text { Sazima and Bokermann, } 1978\end{array}$ & GO,TA & - & Unknown & EN & - & LC & LT,ZC \\
\hline $\begin{array}{l}\text { Leptodactylus fuscus } \\
\text { (Schneider, 1799) }\end{array}$ & $\begin{array}{c}\text { AL,AN,AR,AS,BA, } \\
\text { CA,CM,DA,FI,GA,GO, } \\
\text { GU,LG,MA,MU,NO, } \\
\text { PA,PI,PL,PO,PR, } \\
\text { PX,SA,SS,WA }\end{array}$ & AT,FF,OA & Po & WD & APA,PEJ & LC & $\mathrm{FS}, \mathrm{LT}, \mathrm{ZC}$ \\
\hline $\begin{array}{l}\text { Leptodactylus labyrinthicus } \\
\text { (Spix, 1824) }\end{array}$ & $\begin{array}{c}\text { AG,AL,AN,AR,AS, } \\
\text { AU,BA,CA,DA,GA, } \\
\text { LG,MA,MU,NA,NO, } \\
\text { PA,PI,PL,PM,PR,SA,SS,WA }\end{array}$ & AT,FF,OA & Po,St & WD & $\begin{array}{l}\text { APA,PEC, } \\
\text { PEJ }\end{array}$ & LC & $\mathrm{FS}, \mathrm{LT}, \mathrm{ZC}$ \\
\hline $\begin{array}{l}\text { Leptodactylus macrosternum } \\
\text { Miranda-Ribeiro, } 1926\end{array}$ & $\begin{array}{c}\text { AG,AN,AR,AS,BA, } \\
\text { CA,DA,FI,GO,GU,LG, } \\
\text { MA,NO,NR,PA,PE,PI, } \\
\text { PL,PM,PO,PX,SA,SF,WA }\end{array}$ & AT,OA & Po & DB & $\begin{array}{l}\text { APA,PEC, } \\
\text { PEJ }\end{array}$ & LC & FS,LT, ZC \\
\hline $\begin{array}{l}\text { Leptodactylus mystaceus } \\
\text { (Spix, 1824) }\end{array}$ & $\begin{array}{c}\text { AL,AN,AS,BA,CA, } \\
\text { GU,LG,NO,PA,PE,PI,PL,PO }\end{array}$ & AT,FF,OA & Po,St & WD & APA,PEC & LC & FS,LT, ZC \\
\hline $\begin{array}{l}\text { Leptodactylus mystacinus } \\
\text { (Burmeister, 1861) }\end{array}$ & AL,AS,BA,GA,PA,PX & AT,FF,OA & Po,St & $\mathrm{AT}$ & - & LC & $\mathrm{FS}, \mathrm{LT}, \mathrm{ZC}$ \\
\hline $\begin{array}{l}\text { Leptodactylus podicipinus } \\
\text { (Cope, } 1862 \text { ) }\end{array}$ & $\begin{array}{l}\text { AG,AN,AR,BA,CA,DA, } \\
\text { DI,GO,LG,MA,PA, } \\
\text { PL,PO,PX,SA,WA }\end{array}$ & $\mathrm{AT}, \mathrm{FF}, \mathrm{OA}$ & Po & DB & PEC,PEJ & LC & $\mathrm{FS}, \mathrm{LT}, \mathrm{ZC}$ \\
\hline $\begin{array}{l}\text { Leptodactylus pustulatus } \\
\text { (Peters, 1870) }\end{array}$ & $\begin{array}{c}\text { AG,AN,BA,CA,CM, } \\
\text { FI,GA,GU,LG,PA, } \\
\text { PL,PO,PX,SF }\end{array}$ & AT,OA & Po,Ri & EN & - & LC & $\mathrm{FS}, \mathrm{LT}, \mathrm{ZC}$ \\
\hline $\begin{array}{l}\text { Leptodactylus sertanejo } \\
\text { Giaretta and Costa, } 2007\end{array}$ & MA & $\mathrm{OA}$ & Unknown & EN & PEJ & LC & LT \\
\hline $\begin{array}{l}\text { Leptodactylus syphax } \\
\text { Bokermann, } 1969\end{array}$ & GA,MA,NO,PA,PL,PO & OA & Po,St & DB & APA,PEJ & LC & FS,LT, ZC \\
\hline $\begin{array}{l}\text { Leptodactylus troglodytes Lutz, } \\
1926\end{array}$ & $\begin{array}{l}\text { AS,BA,DA,GA,MA, } \\
\text { NO,PA,PL,PO }\end{array}$ & OA & Po,St & CA & APA,PEJ & LC & $\mathrm{FS}, \mathrm{LT}, \mathrm{ZC}$ \\
\hline $\begin{array}{l}\text { Leptodactylus sp. } \\
\text { (aff. podicipinus) }\end{array}$ & AG,CA,LG,PI & AT,OA & Po & $?$ & - & $\mathrm{NE}$ & $\mathrm{FS}, \mathrm{ZC}$ \\
\hline $\begin{array}{l}\text { Leptodactylus sp. } \\
\text { (aff. mystaceus)* }\end{array}$ & AS & OA & St & $?$ & - & NE & FS \\
\hline $\begin{array}{l}\text { Lithodytes lineatus } \\
\text { (Schneider, 1799)* }\end{array}$ & AR,CA,FL,PL & $\mathrm{FF}, \mathrm{OA}$ & St & $\mathrm{AM}$ & - & LC & FS,LT \\
\hline $\begin{array}{l}\text { Physalaemus centralis } \\
\text { Bokermann, } 1962\end{array}$ & $\begin{array}{c}\text { AL,AR,AS,BA,CA,DA, } \\
\text { GA,LG,MA,MU, } \\
\text { NO,NR,PA,PL,PO,PT }\end{array}$ & $\mathrm{AT}, \mathrm{FF}, \mathrm{OA}$ & Po & EN & $\begin{array}{l}\text { APA,PEC, } \\
\text { PEJ }\end{array}$ & $\mathrm{LC}$ & $\mathrm{FS}, \mathrm{LT}, \mathrm{ZC}$ \\
\hline $\begin{array}{l}\text { Physalaemus cuvieri Fitzinger, } \\
1826\end{array}$ & $\begin{array}{c}\text { AG,AL,AN,AR,AS,BA, } \\
\text { CO,DA,GA,GO,LG,MA, } \\
\text { MU,NO,NR,PA,PE,PL, } \\
\text { PM,PR,PX,SA }\end{array}$ & AT,FF,OA & Po & WD & APA,PEJ & LC & $\mathrm{FS}, \mathrm{LT}, \mathrm{ZC}$ \\
\hline $\begin{array}{l}\text { Physalaemus nattereri } \\
\text { (Steindachner, 1863) }\end{array}$ & $\begin{array}{c}\text { AL,AS,AU,BA,DA,DI, } \\
\text { FI,LG,MA,PA,PL,PO,PR,PT }\end{array}$ & AT,OA & Po & EN & PEJ & LC & $\mathrm{FS}, \mathrm{LT}, \mathrm{ZC}$ \\
\hline Physalaemus sp. (gr. cuvieri)* & $\mathrm{CA}$ & AT,OA & Po,St & $?$ & PEC & NE & FS \\
\hline $\begin{array}{l}\text { Pleurodema diplolister } \\
\text { (Peters, 1870)* }\end{array}$ & AS,MA,PR & OA & Po,St & CA & PEJ & $\mathrm{LC}$ & $\mathrm{FS}, \mathrm{LT}, \mathrm{ZC}$ \\
\hline
\end{tabular}




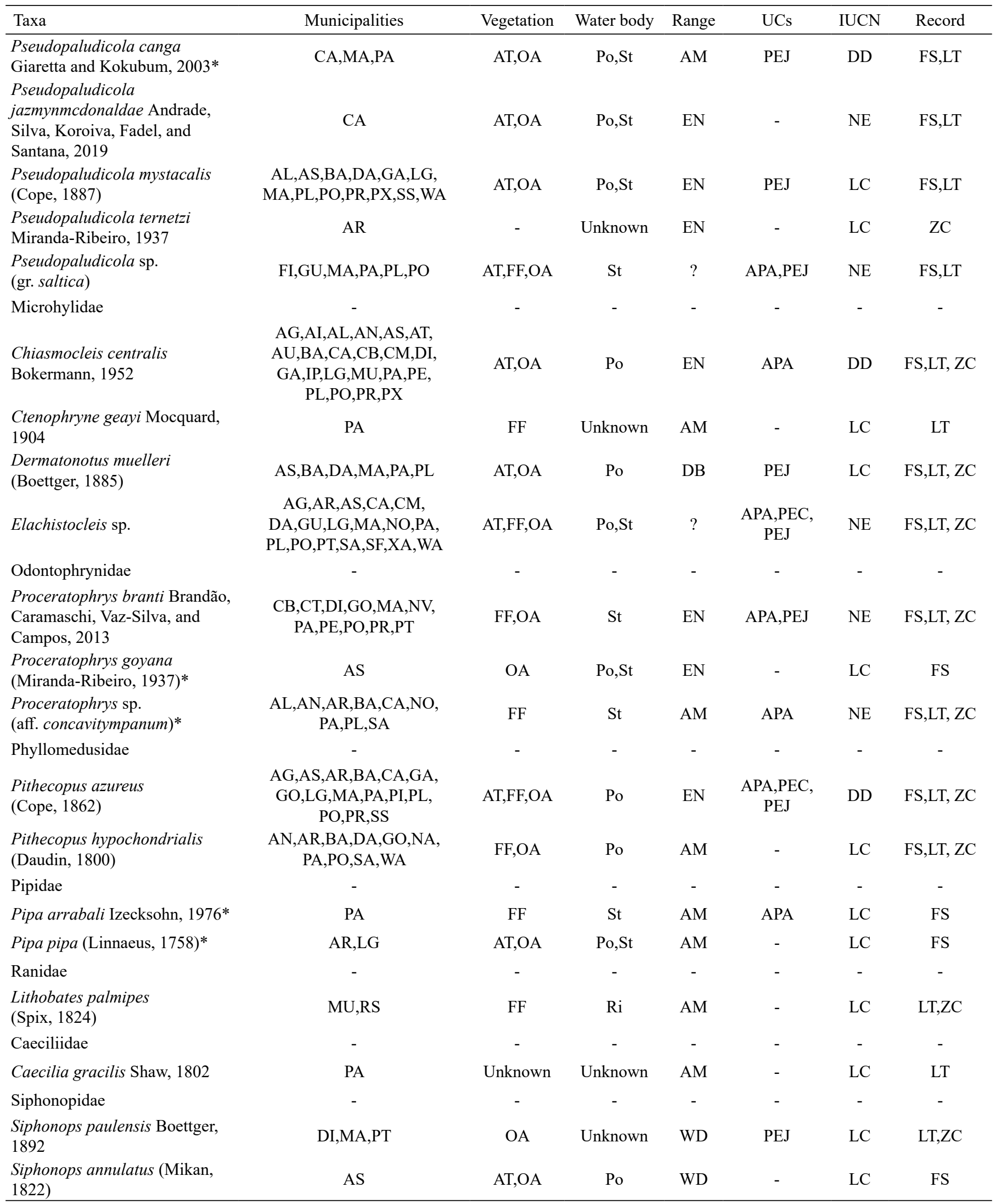




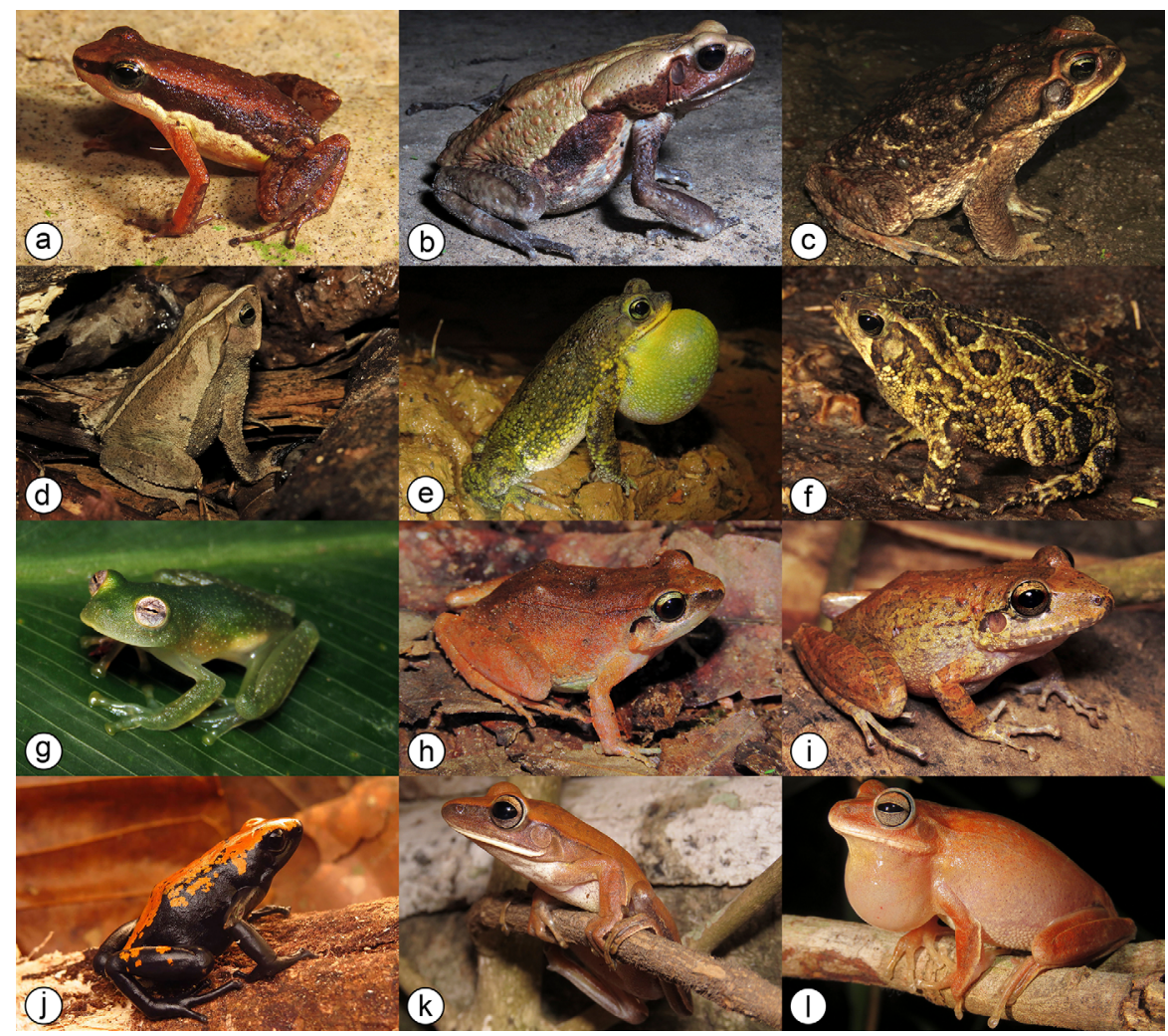

Figure 2. Amphibian species recorded in the State of Tocantins. Aromobatidae: a) Allobates crombiei; Bufonidae: b) Rhaebo guttatus; c) Rhinella diptycha; d) Rhinella gildae; e) Rhinella mirandaribeiroi; f) Rhinella ocellata; Centrolenidae: g) Hyalinobatrachium taylori; Craugastoridae: h) Barycholos ternetzi; i) Pristimantis sp. (aff. fenestratus); Dendrobatidae: j) Adelphobates galactonotus; Hylidae: k) Boana albopunctata; 1) Boana caiapo. Photo “d” and “j” by Silionamã Pereira Dantas; all others by Leandro Alves da Silva.

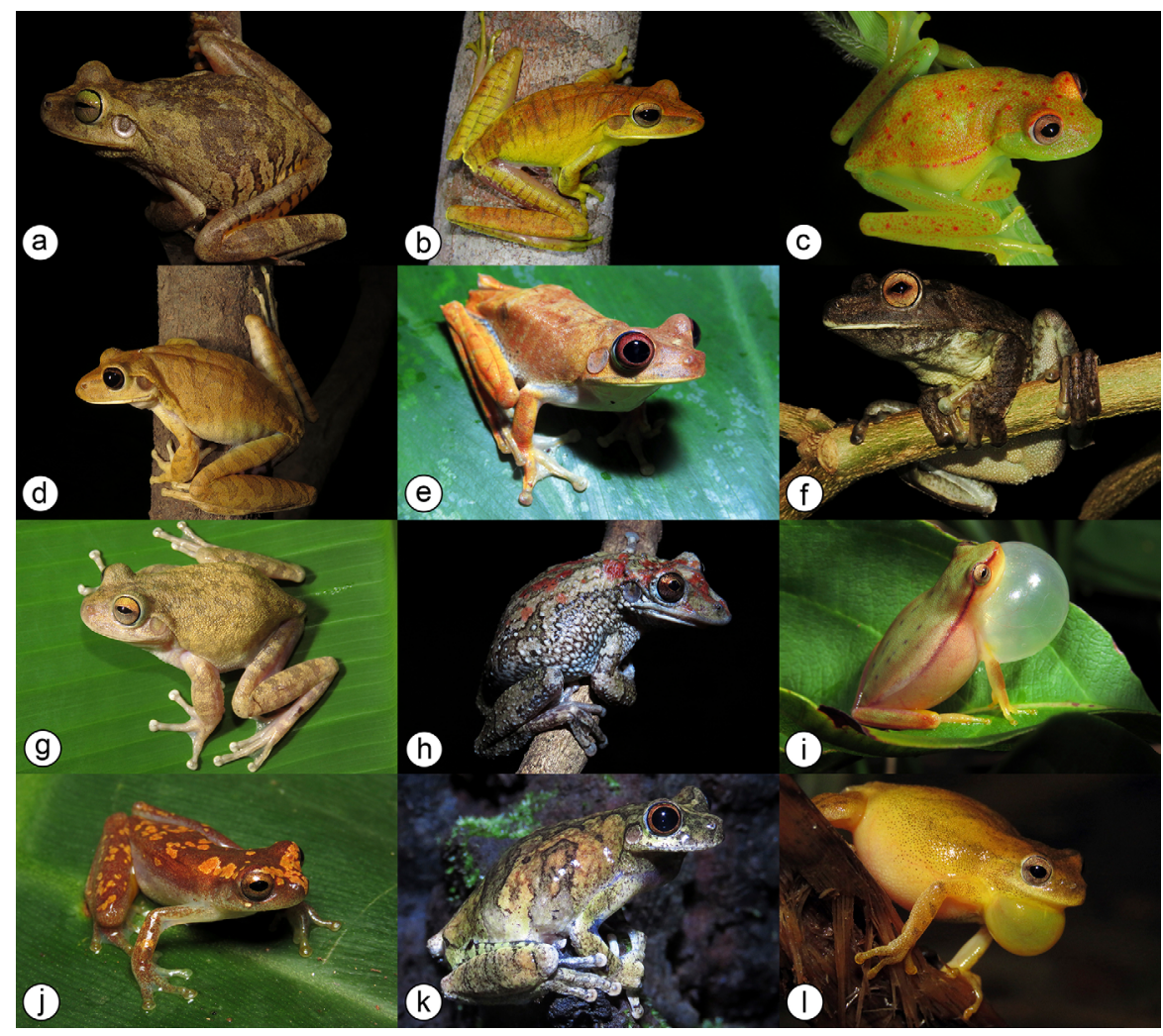

Figure 3. Amphibian species recorded in the State of Tocantins. Hylidae: a) Boana crepitans; b) Boana multifasciata; c) Boana punctata; d) Boana raniceps; e) Boana sp. (aff. semilineata); f) Boana sp. (cf. wavrini); g) Bokermannohyla pseudopseudis; h) Corythomantis greeningi; i) Dendropsophus anataliasiasi; j) Dendropsophus cruzi; k) Dendropsophus melanargyreus; 1) Dendropsophus minutus. Photos by Leandro Alves da Silva. 


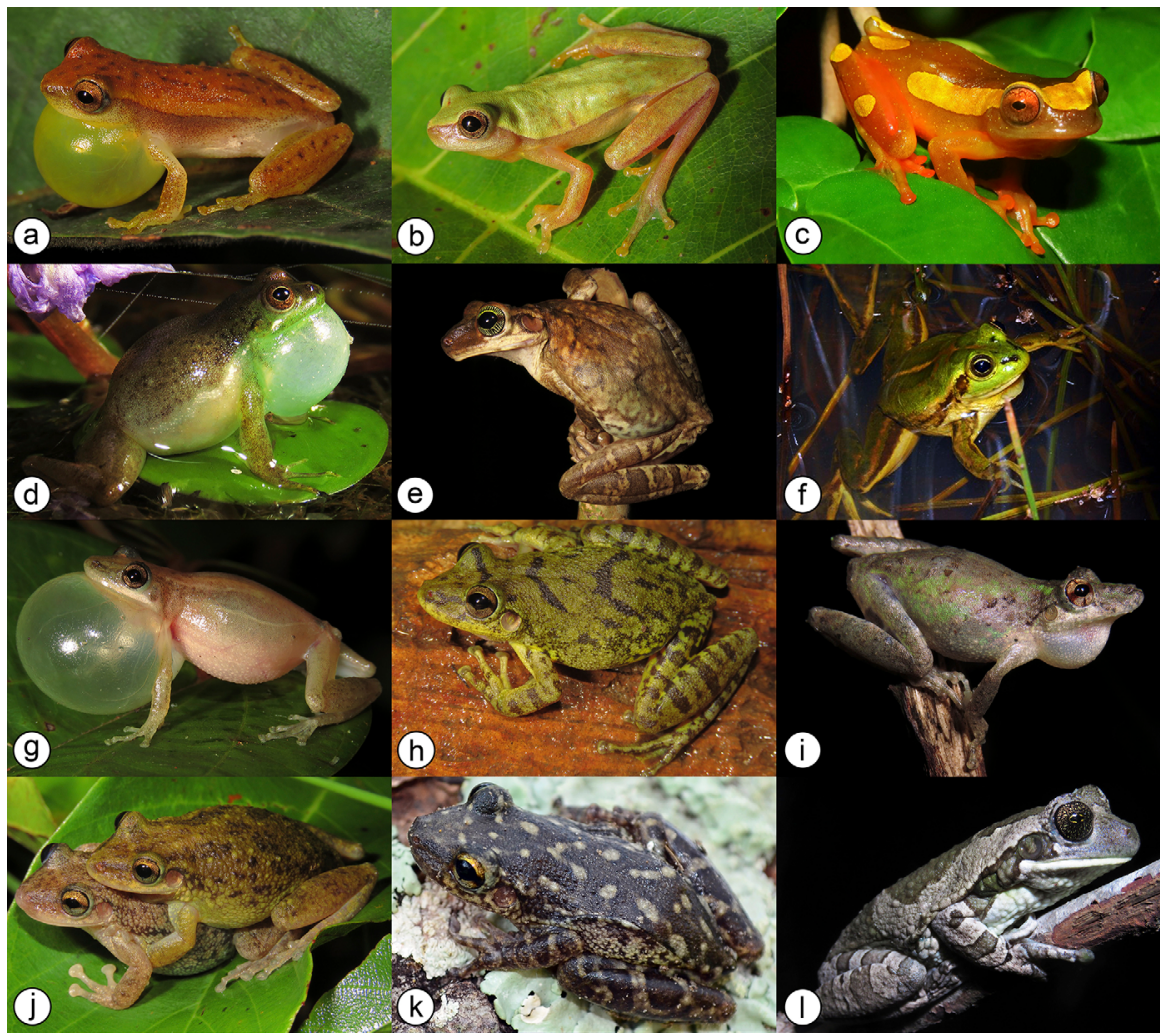

Figure 4. Amphibian species recorded in the State of Tocantins. Hylidae: a) Dendropsophus nanus; b) Dendropsophus rubicundulus; c) Dendropsophus sp. (gr. leucophyllatus); d) Lysapsus caraya; e) Osteocephalus taurinus; f) Pseudis tocantins; g) Scinax fuscomarginatus; h) Scinax fuscovarius; i) Scinax nebulosus; j) Scinax x-signatus; k) Scinax sp. (gr. ruber); 1) Trachycephalus typhonius. Photo "c" by Silionamã Pereira Dantas; photo " $\mathrm{f}$ " by Wanieulli Pascoal; all others by Leandro Alves da Silva.

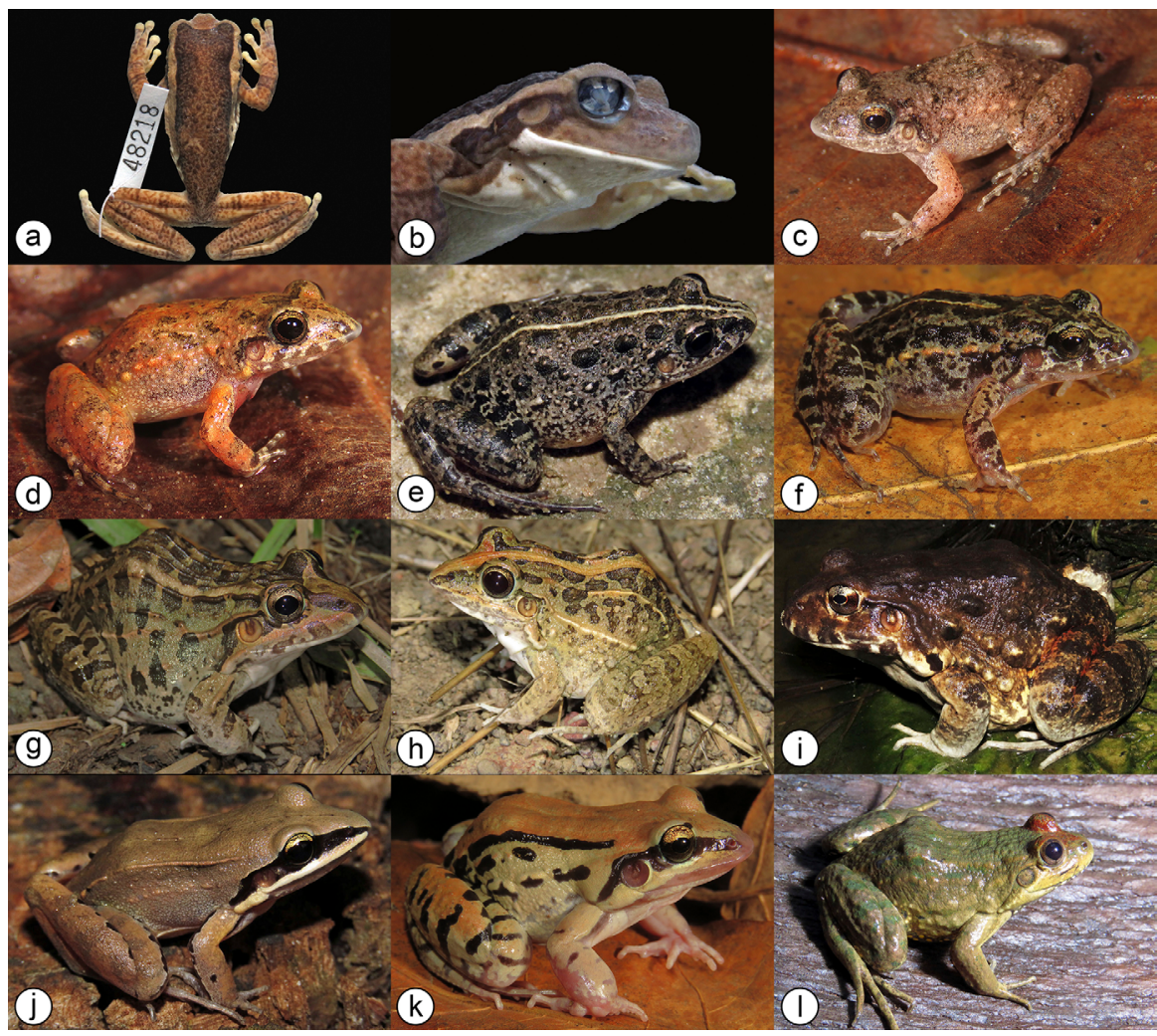

Figure 5. Amphibian species recorded in the State of Tocantins. Hylidae: a) Trachycephalus sp.; b) Trachycephalus sp.; Leptodactylidae: c) Adenomera cotuba; d) Adenomera juikitan; e) Adenomera saci; f) Adenomera sp. 1; g) Leptodactylus chaquensis; h) Leptodactylus fuscus; i) Leptodactylus labyrinthicus; j) Leptodactylus mystaceus; k) Leptodactylus mystacinus; 1) Leptodactylus pustulatus. Photos by Leandro Alves da Silva. 


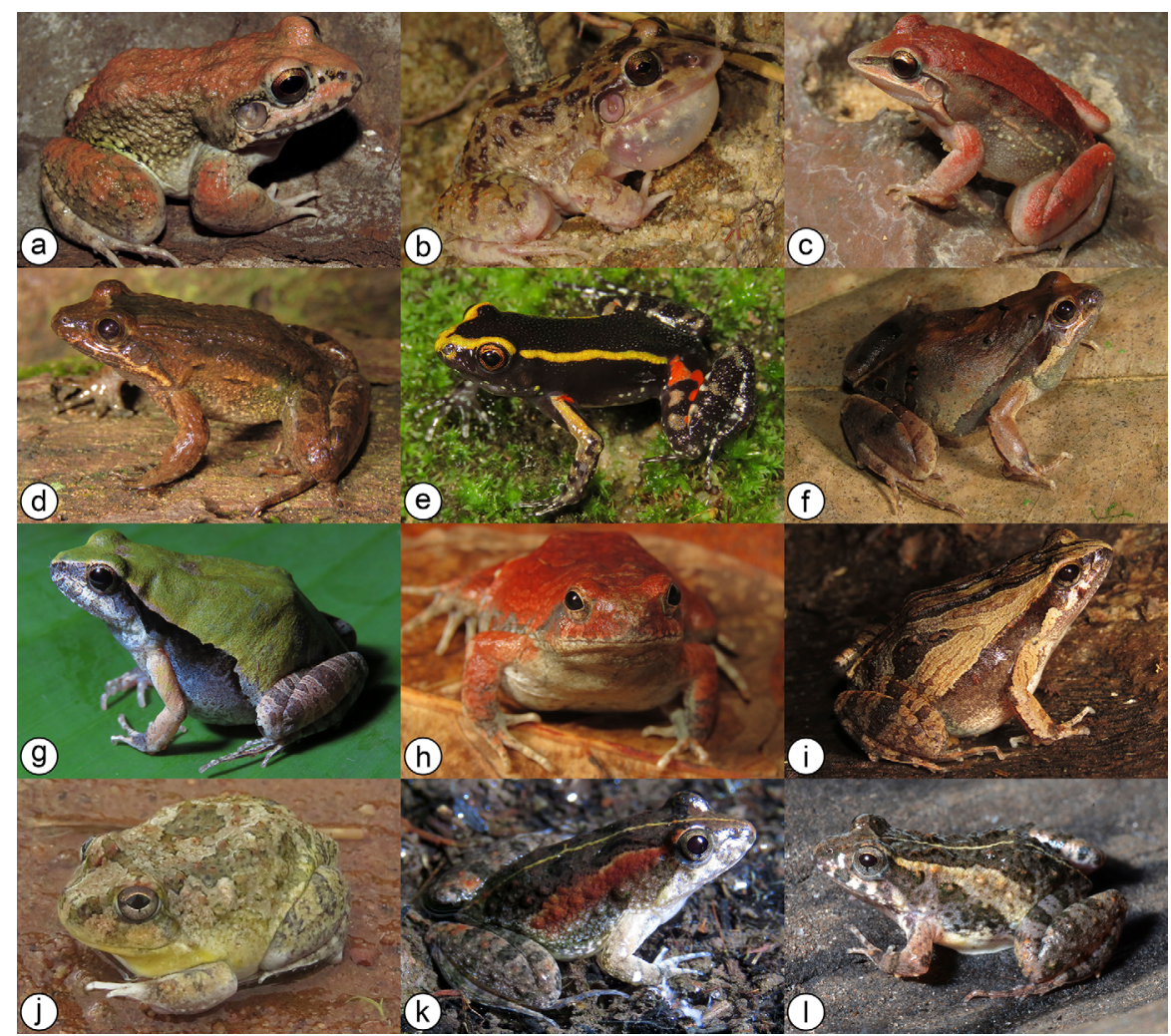

Figure 6. Amphibian species recorded in the State of Tocantins. Leptodactylidae: a) Leptodactylus syphax; b) Leptodactylus troglodytes; c) Leptodactylus sp. (aff. mystaceus); d) Leptodactylus sp. (gr. melanonotus); e) Lithodytes lineatus; f) Physalaemus centralis; g) Physalaemus cuvieri; h) Physalaemus nattereri; i) Physalaemus sp. (gr. cuvieri); j) Pleurodema diplolister; k) Pseudopaludicola canga; 1) Pseudopaludicola jazmynmcdonaldae. Photo "j" by Silionamã Pereira Dantas; photo "l" by Diego Santana; all others by Leandro Alves da Silva.

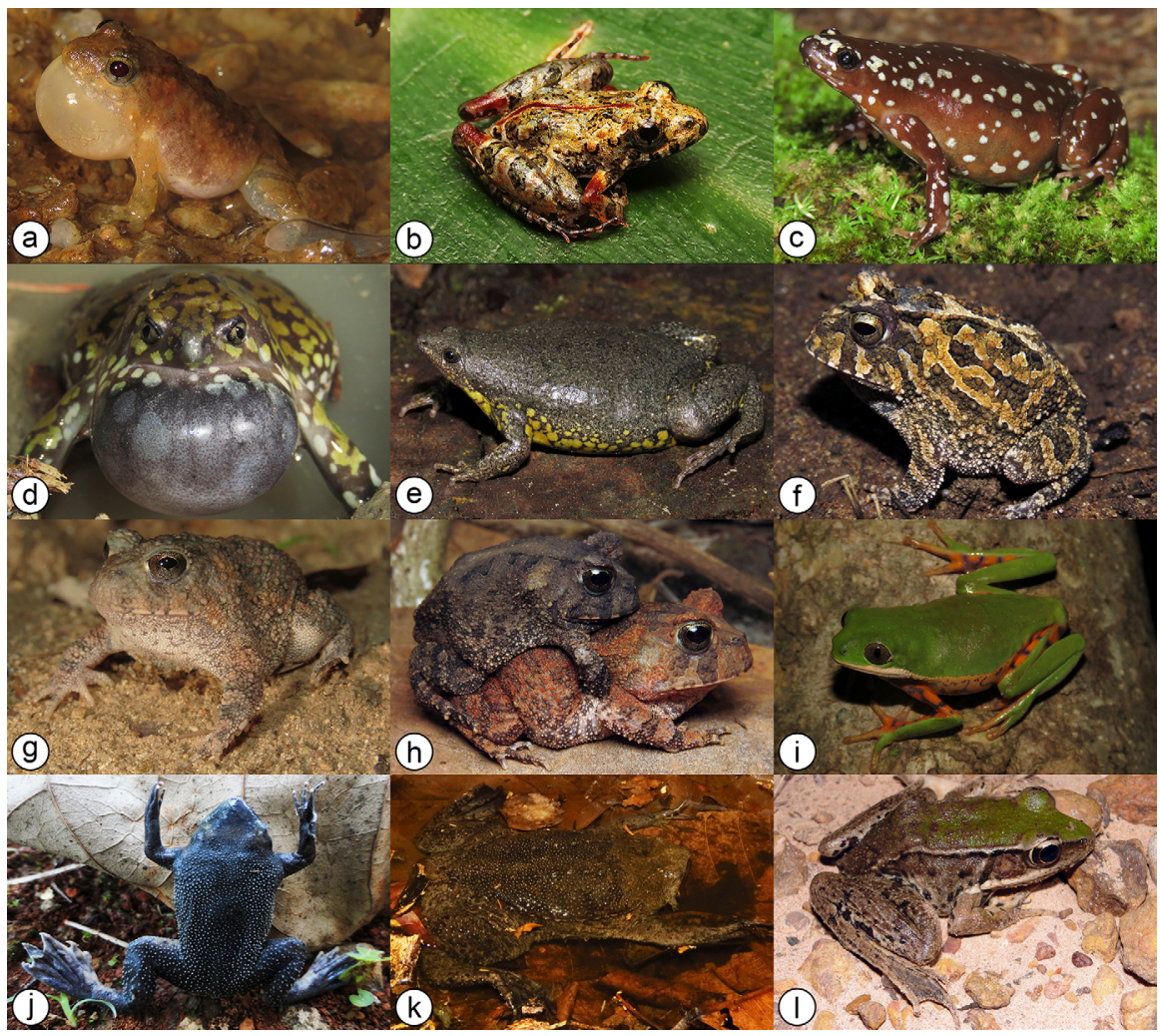

Figure 7. Amphibian species recorded in the State of Tocantins. Leptodactylidae: a) Pseudopaludicola mystacalis; b) Pseudopaludicola sp. (gr. saltica); Microhylidae: c) Chiasmocleis centralis; d) Dermatonotus muelleri; e) Elachistocleis sp.; Odontophrynidae: f) Proceratophrys branti; g) Proceratophrys goyana; h) Proceratophrys sp. (aff. concavitympanum); Phyllomedusidae: i) Pithecopus azureus; j Pipidae:) Pipa arrabali; k) Pipa pipa; Ranidae: 1) Lithobates palmipes. Photo "k" by Silionamã Pereira Dantas; photo "l” by Danusy Lopes Santos; all others by Leandro Alves da Silva. 


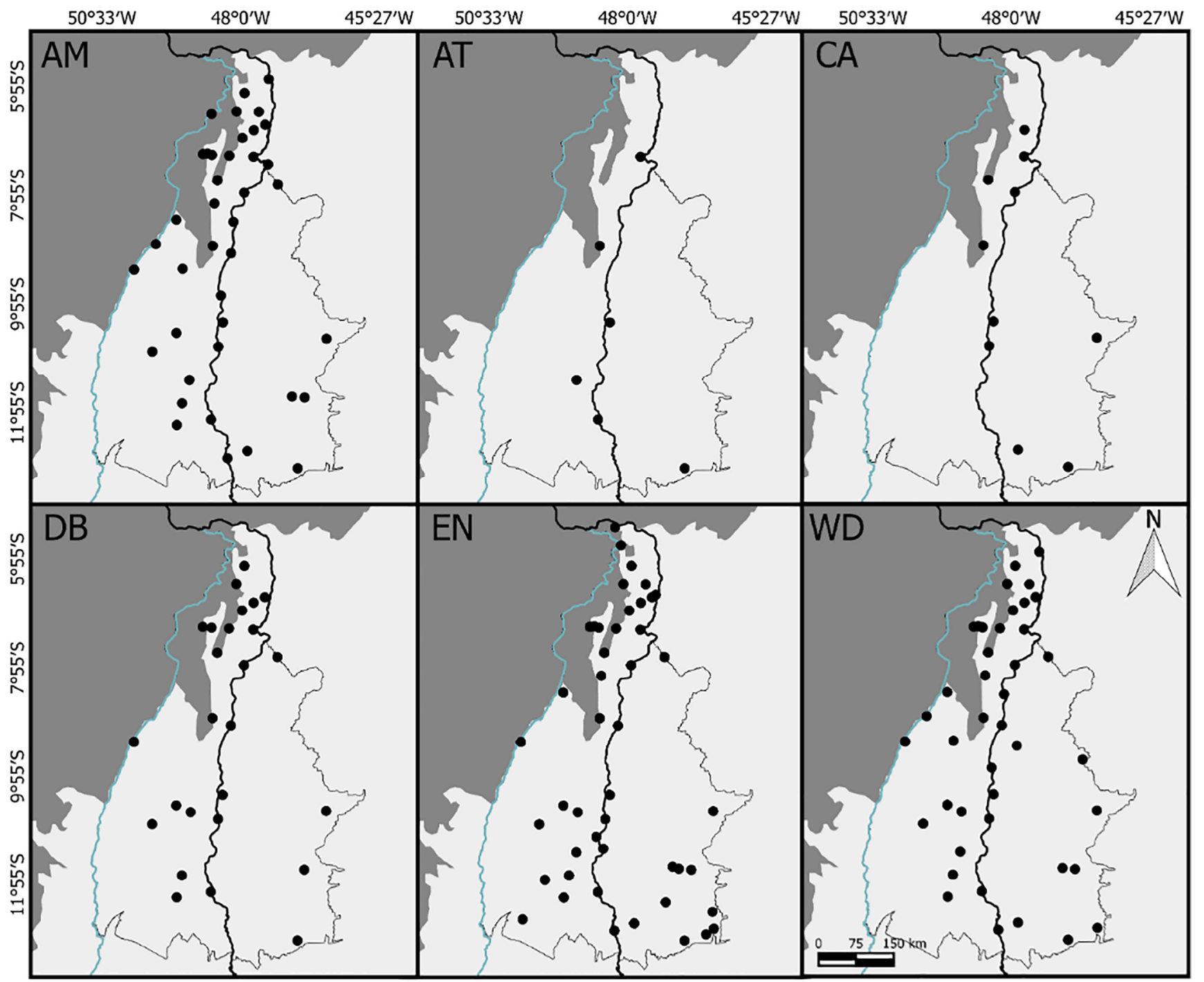

Figure 8. Distribution of amphibian species from different biomes in the State of Tocantins. AM: species of amphibians shared between Amazonia and Cerrado, AT: species of amphibians shared between Atlantic Rain Forest and Cerrado, CA: species of amphibians shared between Caatinga and Cerrado, DB: species distributed through the South American diagonal of open formations, EN: Cerrado endemic species, and WD: species distributed in three or more South American biomes. Biomes - Dark grey: Amazonia, Light grey: Cerrado. Rivers - line light blue: Araguaia River, line black: Tocantins River.

nearly $40 \%$ of the Tocantins municipalities (Figure 1). Around 52\% (n= 29) of these municipalities had between 1 and 10 recorded species, $13 \%$ $(\mathrm{n}=7)$ between 11 and 20 species, $18 \%(\mathrm{n}=10)$ between 21 and 30 species, $13 \%(n=7)$ between 31 and 40 species, $4 \%(n=2)$ between 41 and 50 species, and just $2 \%$ (only the municipality of Palmas) between 51 and 60 species. The richest municipalities of the Tocantins in species of amphibians were Palmas ( $57 \mathrm{spp}$.), Caseara (42 spp.), Palmeirante (41 spp.), and Mateiros (40 spp.). We also reported seven undescribed species registered along the state, Adenomera sp. 1, Adenomera sp. 2, Boana sp. (aff. semilineata), Leptodactylus sp. (aff. mystaceus), Pristimantis sp. (aff. fenestratus), Proceratophrys sp. (aff. concavitympanum), and Trachycephalus sp. Additionally, we found some amphibian lineages that need further appraisal to define their specific identification, as Boana sp. (cf. wavrini) (Figure 3f) and Dendropsophus sp. (gr. leucophyllatus) (Figure 4c). A detailed discussion on these taxonomical issues are provided in the session Remarks on Taxonomy.

\section{Diversity patterns}

Most of the Tocantins amphibian diversity correspond to Cerrado endemic species $(\mathrm{n}=29$, as Bokermannohyla pseudopseudis and Rhinella ocellata), followed by Amazonian frog species $(\mathrm{n}=24$, as Pipa arrabali and Hyalinobatrachium taylori), widely distributed species ( $\mathrm{n}=19$, as Boana raniceps and Rhinella diptycha), Caatinga frogs species $(\mathrm{n}=4$, as Corythomantis greeningi and Pleurodema diplolister), species that occur throughout the South American diagonal of open formations $(\mathrm{n}=4$, as Leptodactylus syphax and Dermatonotus muelleri), and one species shared with the Atlantic Forest, Leptodactylus mystacinus (Table 2). We cannot determine the distribution range for nine recorded species, mainly because they present complex and unsolved taxonomy, such as belonging to problematic species complex, as Scinax sp. (gr. ruber), or actually represent undescribed and poor known lineages, as Leptodactylus sp. (aff. mystaceus). 
We did not observe a clear geographic separation in the distribution of amphibians from different biomes throughout the Tocantins (Figure 8), except regarding to amphibian's species from Caatinga, which were slightly restricted to the eastern portion of the state, on the right bank of the Tocantins River (Figure 8). In summary, we found that species typically from different biomes have their distributions strongly overlapped within the state.

\section{New records}

Twenty new records were found to Tocantins amphibian fauna (Table 2). Nine of these new records correspond to Amazonian frog species mainly associated to gallery forests, including Allobates crombiei and Pipa pipa, four new records for Cerrado endemic frogs, as Adenomera cotuba and Proceratophrys goyana, and one typical Caatinga frog species, Pleurodema diplolister. We also provide a new record for the widely distributed treefrog Boana crepitans. The other five new records comprise undescribed species, and will be addressed in the session Remarks on Taxonomy.

\section{Status of conservation and habitat use}

Of the 90 recorded species, 53 were assigned as least concern (LC) by IUCN criteria, 32 were not evaluated (NE), and five are data deficient (DD) (Table 2); we were not able to identify at the species level 14 lineages, and thus no conservation status was attributed to them. From all recorded species, 57 were reported to occur at least in one of the following three conservation units in Tocantins, two of integral protection, the Parque Estadual do Jalapão (with $40 \mathrm{spp}$.) and Parque Estadual do Cantão (with 16 spp.), and one of sustainable use, the Área de Proteção Ambiental Serra do Lajeado (with 37 spp.) (Table 2). Regarding the type of vegetation where each species was registered, we found 20 species exclusively occurring in forested formations (e.g. gallery forest), most of them (13 spp.) Amazonian species. Other 10 species were found only in open Cerrado formations, mainly represented by Cerrado endemic species. Twenty-four species were found in all phytophysiognomies, most of them (12 spp.) considered widely distributed along the Brazil or South America (Table 2). Regarding water body explored by the species, 25 were reported only in temporary ponds, 21 only in streams, and one only in rivers. The water body use is unknown for 13 species registered only by analyses of literature and/or zoological collections data. The other 30 species were recorded for more than one type of water bodies.

\section{Discussion}

\section{Richness}

The amphibian fauna in the northern portion of the Cerrado has been historically recognized as less rich than the south of this biome, something often attributed to a sampling artefact (Diniz-Filho et al. 2005, 2007, Valdujo et al. 2012). Here we show that the Tocantins state, which is occupied up to $90 \%$ by the Cerrado, holds a notable fauna of amphibians, highlighting that the northern Cerrado may be as highly diversified as the south of this biome. The richness of amphibians along the state is also deeply influenced by the presence of a high number of amphibian Amazonian lineages, even throughout Cerrado areas, where them occurs mainly in forest environments as gallery and riparian forests.
In fact, the northern portion of the state is largely occupied by the Amazonian biome, and there are extensive transitional areas between Amazonia and Cerrado along the west borderline of the state. Despite the high richness of amphibians presented here, we point out two observations that indicates that this number will certainly increase after further investigations. First, nearly $60 \%$ of the Tocantins municipalities have no information on amphibians, and more than half of the municipalities with some data about its amphibian fauna showed just a low number of species (i.e. between 1 and $10 \mathrm{spp}$.). Second, we found that the areas with the most diversified amphibian fauna were located in municipalities where long-term surveys were performed, in which we unveiled several unprecedented records, including at least seven undescribed species, representing about $8 \%$ of the total registered species. In addition, unique environments through the state remain poorly known, and further sample efforts along them may render additional new records and the recognition of undescribed species. Such environments are the mountaintops presents in Almas, Dianópolis, and Natividade municipalities (southeast of the state), the valleys of gallery forests between Palmas, Paraíso, and Porto Nacional municipalities (center of the state, a region of strong influence of the Tocantins river basin), and the northern of the Tocantins (Bico do Papagaio region), where the Amazonian biome is present. Thus, improve our knowledge on the Tocantins amphibian diversity requires intensive sampling efforts throughout the gaps of information above mentioned. We also highlight that many populations with taxonomic problems were found in the study area and we strongly suggest that taxonomical studies aiming solve these problems need to be performed under an integrative taxonomy perspective (see session Remarks on Taxonomy).

\section{Diversity Patterns}

On a regional scale, the amphibian fauna shared among the Cerrado and its neighboring biomes (Amazonia in northwest; Caatinga in northeast; Atlantic Forest in southeast; and Chaco in southwest) is geographically structured, and most of these shared species have a marginal distribution in the Cerrado (Valdujo et al. 2012). In the Tocantins state, however, we found extensive overlaps on the distribution of amphibian species from the Cerrado, Amazonia, and Caatinga. Thus, no clear regionalization was detected analyzing our dataset concerning the amphibian species from different biomes within the Tocantins. In fact, many records of Amazonian and Caatinga species were found deeply within the Cerrado biome, showing that these species are not only marginal ones (e.g. Corythomantis greeningi and Hyalinobatrachium taylori).

We briefly discuss two putative processes, not necessarily mutually exclusives, which may have promoted the striking overlapped distribution pattern described here. First, during the Quaternary, the climate of the Neotropics was unstable and several warm-moist and dry-cold periods were driven by glaciations cycles (Carnaval \& Bates 2007, Hoorn et al. 2010, Werneck et al. 2012). These climate fluctuations are known to have caused expansions and retractions cycles of the South American biomes (Haberle \& Maslin 1999, Auler et al. 2004, Werneck 2011, Baker \& Frits 2015). During glacial periods, the world climate become drier and colder, favoring the expansion of open biomes (e.g. Caatinga, Cerrado and Chaco) and the retraction of forested ones (e.g. Amazonia and Atlantic Forest). On the other hand, during interglacial periods the world climate was 
warmer and moist and the forest biomes expanded their distribution while the open biomes retracted. These climate fluctuations are also assumed as important drivers of demographic events (e.g. expansions and bottlenecks) of some populations of amphibian species (e.g. Carnaval \& Bates 2007, Fouquet et al. 2012, Gehara et al. 2014, Azevedo et al. 2016). Given the central geographic position of the State of Tocantins relative to different Brazilian biomes, different amphibians populations from Amazonia, Caatinga, and Cerrado found throughout the state would have become mixed after recurrent cycles of expansion-retraction. Second, we also point out that the large patches of forest habitats along the Araguaia and Tocantins rivers valleys may have experienced more stable climate in the past and acted as historical dispersal corridors, connecting core areas of Cerrado (where these rivers are born) and Amazonia (where they reach to the sea). In fact, the State of Tocantins is located in an extensive ecotone zone, especially between Amazonia and Cerrado (Ab'Saber 1977). The potential effects of these factors may explain $i$ ) why we did not observe a clear structuration of the geographic distribution of amphibians from different biomes in the state and $i$ ) why Amazonian amphibian lineages largely contributed to the overall amphibian diversity in Tocantins, even this state being mainly covered by the Cerrado biome.

\section{New records}

The present paper represents the first large effort to record the fauna of amphibians of the State of Tocantins. Many new distribution records were found (see Table 2), and we provide comments on the more notables. Some these new records represent undescribed species, and comments on them are presented along the session Remarks on Taxonomy.

The first new record presented here is for the Amazonian species Allobates crombiei (Aromobatidae) (Figure 2a), previously known only from two localities, in the drainage of the lower Xingú River (Lima et al. 2012). We found new populations of this species in five municipalities through the Tocantins, Xambioá and Araguaína (north of the state), Caseara (west of the state), and Lajeado and Palmas (both in the central portion of the state). These reports extend the range of this species in a straight line (as well as for all other records henceforth) nearly $575 \mathrm{~km}, 620 \mathrm{~km}, 780 \mathrm{~km}, 840 \mathrm{~km}$, and $880 \mathrm{~km}$ respectively in a southwestern direction from Altamira municipality. All these populations were found inhabiting forests environments, both along the Araguaia (e.g. Xambioá and Caseara) and Tocantins (e.g. Lajeado and Palmas) rivers basins, where we collected several calling males during diurnal surveys. In fact, this species was very common in all these localities during the rainy season, easily found due its very conspicuous advertisement call and abundance (Lima et al. 2012). Mainly based on morphological evidence, some authors have attributed the name 'Allobates aff. brunneus' for populations of this species in the Babaçulândia and Guaraí municipalities (north of the state) (Pavan 2007, Valdujo et al. 2012). However, this species can be easily diagnosed through its advertisement call (Lima et al. 2012), and ours field expeditions able us to reach the species level identification for these populations along the Tocantins. The new records for this species are extremely important, once the previous known populations of $A$. crombiei relies on a highly endangered area, where the large Belo Monte hydroelectric power plant was implanted (Fearnside 2009). The new records provided here show that Allobates crombiei, rather than an Amazonian microendemic species, is distributed from core Amazonia areas to nuclear Cerrado areas. The fact that this abundant and conspicuous species have been reported only nowadays in the Tocantins show how the amphibian fauna of this state was poorly known. We also stress that no additional species of Allobates was heard or collected during the field surveys.

The family Centrolenidae Taylor 1951 currently comprises 156 nominal species (Frost 2019), with most of them restricted to forest biomes throughout South and Central America (Castroviejo-Fisher et al. 2014, Frost 2016). Nowadays, only three Centrolenidae species have known populations in the Cerrado, Vitreorana aff. eurygnata, $V$. aff. uranoscopa, and $V$. franciscana Santana, Barros, Pontes \& Feio, 2015 (Valdujo et al. 2012, Cintra et al. 2013, Santana et al. 2015, Paz et al. 2019). Here, we present the first report of a Hyalinobatrachium species occurring in the Cerrado, H. taylori (Figure 2g). Hyalinobatrachium taylori was rare in the present study, found during only two of the several field expeditions performed between 2012-2018 in a gallery forest that surround the Roncadeira waterfall (450-550m above sea level), Taquaruçu district, Palmas municipality. The previous known geographic distribution for this species encompasses the north of the South America, along the Guianan Shield, throughout the Surinam, Guyana, French Guiana, and southeastern Venezuela. Morphologically, the population reported here is undiagnosable from the nominal species Hyalinobatrachium taylori (Goin, 1968). Thus, the present record is nearly $1500 \mathrm{~km}$ far away from the nearest and type locality of H. taylori, New River, Guyana (Frost 2019). We highlight, however, that the nominal $H$. taylori may be compose by at least two different lineages, once the genetic distance among individuals from low and high altitudes along the type locality region reaches more than $3 \%$ in 16S mtDNA (Castroviejo-Fisher et al. 2011). At this moment, the acoustic repertory of the population from Palmas wasn't recorded, and this type of evidence may change our interpretation on the taxonomical status of this lineage. The present record show that Hyalinobatrachium species are not exclusive of Rain Forest biomes (Guayasamin et al. 2009, Castroviejo-Fisher et al. 2014), and raises questions on which process could be responsible for the presence of a highly disjoint population found in some gallery forests embedded in a savanna landscape.

We also found new reports for two Amazonian Pipidae Gray 1825 species, Pipa arrabali and P. pipa. The currently known Brazilian distribution of Pipa arrabali encompass just five localities through the Amazonia biome. Two of these localities are in the Amazonas state, the type locality, Parintins municipality (Trueb \& Cannatella 1986), and the capital Manaus (Gascon 1992), one in the Pará state, Serra do Cachimbo, Novo Progresso municipality (Garda et al. 2006), one in the Rondônia state, Parque Municipal de Pimenta Bueno, Pimenta Bueno municipality (Sousa \& Bernarde 2007), and one in the Mato Grosso state, Parque Estadual do Cristalino, Novo Mundo municipality (Rodrigues et al. 2015). Here we present a new report of $P$. arrabali in the Roncadeira waterfall, Taquaruçu district, Palmas municipality, extending the range of this species about $750 \mathrm{~km}$ from the nearest known Amazonian populations (i.e. Serra do Cachimbo and Parque Estadual do Cristalino). This record represents the first report of $P$. arrabali both for the Cerrado and Tocantins state (Trueb \& Cannatella 1986). Only one specimen of this species was captured using pitfall traps (four buried buckets in a "Y" shape, connected by drift fences) inside a gallery forest in the beginning of the rainy season of 2013. Surveys using sieves along water bodies in this area were performed, but no 
additional individual was found. The second species of the Pipa genus, $P$. pipa, was previously known to occur in the Cerrado, in Bonópolis municipality, Goiás state (Vaz-Silva \& Andrade 2009). The reports presented here in the Dois Rios Farm, Lagoa da Confusão municipality (southwest of the state) and in the Escola de Medicina Veterinária e Zootecnia (acronym EMVZ), Araguaína municipality (northern of the state) constitutes unprecedented records of $P$. pipa for the Tocantins state. Both municipalities are located in transitional zones between the Amazonia and Cerrado biomes. In Lagoa da Confusão, some specimens were found crossing a dirty road between artificial temporary ponds inside of a rice plantation. In Araguaína, two specimens of this species were captured in a stream in a gallery forest. These records increase the distribution of $P$. pipa in nearly $330 \mathrm{~km}$ and $770 \mathrm{~km}$, respectively, from the nearest known Cerrado population (i.e. Bonópolis municipality, Goiás state). Thus, here we present the first reports of Pipidae species to occur in the Tocantins state.

Additional new records for Amazonian frog species in Tocantins are Boana cinerascens, Pseudopaludicola canga and Sphaenorhynchus lacteus. Boana cinerascens and S. lacteus are species widely distributed throughout the Amazonia (Azevedo-Ramos et al. 2010, La Marca et al. 2010), and here we extended their distributions by the first time for the Tocantins. Some calling males of $B$. cinerascens were collected in a forest fragment in the Escola de Medicina Veterinária e Zootecnia (acronym EMVZ), Araguaína municipality. Two individuals of $S$. lacteus were found on floating macrophytes of temporary ponds near to the Araguaia River, in the Ananás municipality. Both municipalities are transitional zones between Amazonia and Cerrado. Pseudopaludicola canga was previously known for some localities of eastern Pará (Marabá, Curinópolis, São Geraldo do Araguaia, and Conceição do Araguaia municipalities) and Tocantins (Mateiros and Palmas municipalities) (Carvalho et al. 2015b). Here we present a new distribution for $P$. canga in the Caseara municipality, about $150 \mathrm{~km}$ south from the nearest known Pará populations (i.e. Conceição do Araguaia), and about 200 $\mathrm{km}$ west from the nearest known Tocantins populations (i.e. Palmas). In Caseara, Pseudopaludicola canga was syntopic with the recently described Pseudopaludicola jazmynmcdonaldae (Andrade et al. 2019).

Among the new reports to Cerrado endemic frogs, we highlight the record of Trachycephalus mambaiensis for the Combinado municipality, southeastern of the Tocantins. This species was previously known for the Goiás state (Mambaí and São Domingos municipalities), Bahia (Santa Maria da Vitória municipality) and Minas Gerais (Bonito de Minas, Januária, and João Pinheiro municipalities) state (Freitas et al. 2011, Silveira \& Pacheco 2011, Dayrell et al. 2012). This record extends the distribution of $T$. mambaiensis nearly $70 \mathrm{~km}$ from the near known population, in the São Domingos municipality, Goiás, and is the first for the Tocantins state. We also present new records for two recently described species of the Adenomera genus. Adenomera cotuba was previously known for four municipalities, including the type locality Teresina de Goiás, Uruaçu, and Goiânia, Goiás state, and Figueirópolis, Tocantins state (Carvalho and Giaretta 2013a). Recently, an additional record for this species was provided for São Desidério municipality, Bahia state (Oliveira et al. 2018). Here, we report new records for this species to Caseara (west of the state) and Palmas (central portion of the state) municipalities, extending their range nearly $314 \mathrm{~km}$ and $230 \mathrm{~km}$, respectively, from the nearest known locality, the Figueirópolis municipality (southern of the State of Tocantins). The second species, A. juikitam, was known from two municipalities of the Goiás state, the type locality Teresina de Goiás, and Colinas do Sul, in the Chapada dos Veadeiros region (Carvalho \& Giaretta 2013a). During ours field expeditions, we confirm the presence of this species along three municipalities within the Tocantins, Palmas (central portion of the state), Caseara (west of the state), and São Bento do Tocantins (northern of the state), extending the distribution of this species in $395 \mathrm{~km}, 568 \mathrm{~km}, 861 \mathrm{~km}$, respectively, from the nearest and type locality, Teresina de Goiás. As pointed out by the authors that described $A$. cotuba and A. juikitan, we observe both species calling in syntopy in Palmas and Caseara municipalities, and the reliable identification of them was only possible due to the recent improvement of the acoustic knowledge of this genus, depicting the importance of pluralistic source of evidences in diagnoses for these tiny and morphologically conserved group of Leptodactylidae frogs (Carvalho \& Giaretta 2013a, b, Carvalho et al. 2019).

In addition, we found a new report for the typical Caatinga species Pleurodema diplolister, known to have a marginal distribution in Cerrado (Andrade \& Vaz-Silva 2012, Valdujo et al. 2012). Here, we present another population of this species occurring in a more central area of Cerrado, in Paranã municipality (south of the state), increasing its distribution nearly $105 \mathrm{~km}$ from the nearest known Cerrado population, in Arraias municipality, Tocantins (Andrade \& Vaz-Silva 2012). The main vegetation of this locality is Seasonally Dry Tropical Forest formations (acronym SDTF), locally called as 'matas secas'. These environments share close evolutionary history with the Caatinga vegetation (Werneck 2011) and may have influenced the presence of this common Caatinga frog species in the Arraias municipality. Finally, we also report the first record of Boana crepitans for the Tocantins state, also in Arraias municipality, extending its distribution nearly $40 \mathrm{~km}$ north from the near known locality, Monte Alegre de Goiás municipality, Goiás state (Orrico et al. 2017).

\section{Remarks on taxonomy}

Discover new species often lies on intensive field surveys and/ or meticulous analyses of specimens in zoological collections. Equally important is the use of pluralistic lines of evidence to confirm these new and sometimes cryptic species (e.g. Bickford et al. 2006, Padial et al. 2010, Fouquet et al. 2016). Morphological and/or acoustic evidences indicated the existence of at least seven undescribed species along the state. Based on advertisement calls recorded during field works, we were not able to attribute specific names for populations of Adenomera from Caseara and São Bento do Tocantins (Adenomera sp. 1; Figure 5f), and Araguaína (Adenomera sp. 2), suggesting that these populations cannot be assigned to any currently valid species. Thus, here we consider both as undescribed species. Other leptodactylid on similar situation is Leptodactylus sp. (aff. mystaceus). In a recent field expedition in the Arraias municipality, southeastern of the Tocantins, we recorded some calling males morphologically very similar to the species embedded in the L. mystaceus complex, but with a call pattern very distinct of the syntopic L. mystaceus population. The new species pointed here, L. sp. (aff. mystaceus) (Figure 6c), has a call consisting of a single nonpulsed note, while the syntopic L. mystaceus showed the conventional pulsed call pattern. 
Recent studies have revealed a high cryptic diversity within reticulated-eye treefrogs, the Boana semilineata species group (Fouquet et al. 2016, Peloso et al. 2018). One of these cryptic lineages is $B$. aff. semilineata 2 (Fouquet et al. 2016), previously known to occur in Guaraí municipality, Tocantins state, and in Altamira municipality, Pará state. During field samplings and analysis of specimens from collections, we found several specimens of this lineage and confirm its full species status (Figure 3e). Currently, this lineage is known to occur in marshy environments along 10 municipalities in north (Aragominas, Ananás, Araguaína, Babaçulândia, and Guaraí) and western (Caseara, Colinas do Tocantins, Muricilândia, Nazaré, and Santa Fé do Araguaia) of the State of Tocantins.

The Proceratophrys populations found through Tocantins have a complex taxonomic history, and different names were already attributed to a same lineage (e.g. Brandão \& Peres 2001, Pavan 2007, Valdujo et al. 2011, Brandão et al. 2013). Currently, three species of this genus have confirmed presence in the Tocantins, two of these species are described, $P$. branti (Figure 7f) and $P$. goyana (Figure $7 \mathrm{~g}$ ), known for inhabit just Cerrado open formations (Valdujo et al. 2011, Brandão et al. 2013, present work). The third Proceratophrys registered here, $P$. sp. (aff. concavitympanum) (Figure 7h) (Mângia et al. 2018), is easily diagnosable from the two nominal species aforementioned based on its call, that is composed of just one note (personal observation), while $P$. branti and $P$. goyana have calls consisting of multiple notes (Martins \& Giaretta 2013, Andrade et al. 2018). Additionally, P. sp. (aff. concavitympanum) was found exclusively on forest environments, while $P$. branti and $P$. goyana were restrict to open formations of the Cerrado. Most of the distribution of this lineage in the study area encompass the central and northern portion of the state, in the municipalities of Aliança do Tocantins, Ananás, Araguaína, Babaçulândia, Caseara, Nova Olinda, Palmas, and Palmeirante.

The identification of the Pristimantis populations within the state have challenged different specialists (e.g. Pavan \& Dixo 2004, Brasileiro et al. 2008). In fact, any taxonomical appraisal had included populations of Pristimantis from the State of Tocantins, the worst scenario when we are dealing with a group (i.e. Terrarana) where even different genera are hard to distinguish using only morphological characters (Hedges et al. 2008, Heinicke et al. 2009, Padial et al. 2014). Based on molecular and acoustic evidences, all populations of Pristimantis currently known for the Tocantins belongs to a same, but undescribed lineage, herein called as Pristimantis sp. (aff. fenestratus) (Figure 2i) (Oliveira et al. submitted). This species was exclusively recorded within gallery forests of seven municipalities along the Tocantins river, Araguaína, Babaçulândia, Itaguatins, Muricilândia, Palmas, Palmeirante, and São Bento do Tocantins.

The genus Trachycephalus Tschudi, 1838 comprises 17 recognized species distributed along the Central and South America (Frost 2019). In addition to molecular support, the presence of paired vocal is a putative morphological synapomorphy to this genus (Faivovich et al. 2005). However, two Trachycephalus species are known to have a single subgular vocal sac, T. hadroceps (Duellman \& Hoogmoed 1992) and T. helioi Nunes, Suárez, Gordo and Pombal (2013). Here, we suggest a third Trachycephalus candidate species with single subgular vocal sac.
Our statement is based on the analysis of the adult male MNRJ48218 that lack the paired vocal sac (Figure $5 \mathrm{a}, \mathrm{b}$ ), an easily visible structure in adult males of the most Trachycephalus species. The two others species of the genus found in the study area (i.e. T. mambaiensis and T.typhonius) have paired vocal sacs. Besides the absence of paired vocal sacs, the Trachycephalus sp. reported herein can be easily differentiated from $T$. typhonius by the eye ornamentation (banded in candidate species and reticulated in T. typhonius). This species was neither recorded during field surveys nor mentioned in the literature. The MNRJ48218 specimen was collected in the Santa Fé do Araguaia municipality, north of the state, in a transitional area between Amazonia and Cerrado biomes.

We also highlight that some recorded species were not attributed to any nominal species, and further taxonomic investigations are necessary to clarify their taxonomic status. Firstly, we highlight Elachistocleis sp. (Figure 7e), registered in 18 municipalities of all regions of the Tocantins (Table 2). Despite the high similarity in advertisement calls of the Elachistocleis populations herein recorded, we found a notable intra and inter-population variation in venter color pattern and $\mathrm{CRC}$, both diagnostic characters for this some species in this group (Caramaschi 2010, Toledo et al. 2010, Nunes-de-Almeida \& Toledo 2012). Employing a more conservative assumption, we named all populations of this genus found in the state as Elachistocleis sp. Other similar situation occurred with some populations belonged to the Leptodactylus melanonotus, Physalaemus cuvieri, and Scinax ruber species groups found during the present study.

Finally, many recent studies have challenged traditional proposals of amphibian species diagnosis based on morphological data only (e.g. Funk et al. 2011, Bruschi et al. 2013, Brusquetti et al. 2014, Caminer \& Ron 2014, Carvalho et al. 2015, Lourenço et al. 2015, de Sá et al. 2019). For example, the color patterns suggested to distinguish Pithecopus azureus from $P$. hypochondrialis have failed to reliably diagnose these valid species (Caramaschi 2006, Bruschi et al. 2013, Haga et al. 2017). Thus, we call attention to the fact that other nominal and morphologically similar amphibian species reported in this work should be revaluated to confirm their validity and/or to improve their diagnoses. Among the highly morphologically similar species found herein, we can cite Boana boans and B. wavrini, Dendropsophus melanargyreus and D. soaresi, and Scinax constrictus and Scinax nebulosus. The taxonomical status of Boana boans and $B$. wavrini is historically confuse, but these very similar species are currently considered valid (Hoogmoed 1990). During our investigations of the literature and in zoological collections, we found records suggesting the presence of both $B$. wavrini (Brandão \& Peres Jr. 2001; Brasileiro et al. 2008) and B. boans (Pavan \& Dixo 2004) in the State of Tocantins. However, we point out that the distribution of both species is highly associated to Amazonia biome, far from the southern previous records of B. boans and B. wavrini in the State of Tocantins (i.e. Palmas). During ours field expeditions, we collected specimens in Guaraí and Palmas municipalities that we were not able to determine if them belonged to $B$. boans or $B$. wavrini (Figure 3f). Thus, to avoid an artificial inflation on the number of species in the present checklist, we decide to name all populations (including those from literature and zoological collections) as $B$. cf. wavrini. A more accurate investigation of the identity of the populations attributed to $B$. boans and $B$. wavrini along the Tocantins will determine if i) really both species occurs in the state, ii) just one of them or, iii) the Tocantins populations belongs to an undescribed species. 


\section{Conservation and habitat use}

Tocantins is the youngest state of the Brazil and the third less populated (1.496.880 habitants, IBGE 2014). Although anthropic impacts are commonly associated with densely populated regions, areas with low population density can suffer severely due to livestock and predatory agriculture practices (Diniz-Filho et al. 2006, Sano et al. 2010, Rocha et al. 2011). Besides these threats, the establishment of several hydroelectric power plants in the Tocantins River $(n=7)$ has provoked irreversible biodiversity and habitat loss (Pavan 2007, Agostinho et al. 2011, Pelicice et al. 2014, see a study case in Brandão $\&$ Araujo 2008). In the present study, we found many of the Tocantins amphibians using specific phytophysiognomies and water bodies. Therefore, the continuous increase of these anthropic impacts in Tocantins could eliminate singular environments and eventually lead to local extinctions of specialist species.

Tocantins state harbors unique conservation units, varying from wide savanna formations (Parque Estadual do Jalapão) to large transitional zones between Amazonia forest and Cerrado (Parque Estadual do Cantão and Parque Nacional do Araguaia) (Naturatins 2017). Despite the singularity and spatial significance of the conservation units in the state, information about amphibian diversity in these protected areas are often anecdotal or inexistent. Indeed, among the 28 conservation units of the state, comprehensive sampling efforts to study amphibian assemblages were only carried out in the Jalapão region (e.g. Parque Estadual do Jalapão and Estação Ecológica Serra Geral do Tocantins) (Vitt et al. 2005, Valdujo et al. 2011). Legally protected areas have obvious importance to wildlife conservation. However, create protection units without a careful analysis on which areas are priority for biodiversity conservation can decreases the effectiveness of these units (Silvano et al. 2016). Thus, we stress that the creation of future conservation units within the Tocantins should be guided by biodiversity informed decision, taking into account different diversity metrics as endemism, phylogenetic diversity, and evolutionary distinctiveness. Further, the current protected areas urgently need of a comprehensive sampling effort to produce basic information on its diversity, once this kind of information can help us to set appropriate conservation actions to keep their biota safe.

Most of the species recorded herein are categorized as least concern by the IUCN criteria, and five are data deficient. One of these data deficient species is $A$. crombiei, which was previously known to occur only in Altamira municipality, Pará (Lima et al. 2012), a highly threatened region due to the construction of the Belo Monte hydroelectric power plant (Fearnside 2009, Greenpeace 2016). The establishment of hydroelectric power plants causes profound changes to the amphibian diversity in the impacted areas, including local extinctions (Brandão \& Araujo 2008, Lima et al. 2015). In the present work, we provided the first report of this data deficient species outside the impact zone of the Belo Monte hydroelectric plant.

Species richness is an important parameter in order to choose priority areas for conservation (Diniz-Filho et al. 2007). Thus, investigate sampling gaps allow us to diagnose areas that should receive more attention related to conservation. Here, we highlighted the remarkable amphibian diversity of the State of Tocantins and the urgency in protecting the singular amphibian community of the region (Azevedo et al. 2016; Silvano et al. 2016). Crucial steps to conservation purposes include fill the geographical and taxonomic knowledge gaps showed herein.

\section{Final remarks}

In a final appointment on the new records of Amazonia amphibian species in the Tocantins Cerrado, we suggest species as Allobates crombiei, Osteocephalus taurinus, and Pristimantis sp. (aff.fenestratus) as ideal models for investigate the path and chronology of occupation of Amazonia frog lineages into the north Cerrado, once they were very abundant and of easy capture along many sampling sites. Thus, further co-phylogeographic studies can investigate if the current distribution of these species were more influenced by $i$ ) the quaternary climate fluctuations, ii) the potential historical dispersal corridor formed by the forest habitats along the Araguaia and Tocantins basins or, iii) the current distribution of these species resulted from a synergistic interplay of the previous factors.

The Tocantins amphibian fauna is highly diversified and composed by species from different biomes, especially Amazonian species. Thus, protect areas in Tocantins state also represents maintain a rich evolutionary history of Brazilian amphibians safe (Azevedo et al. 2016, Silvano et al. 2016). In fact, in all sites where we performed intensive and long-term surveys, unnamed species were recorded. Also, inedited records were common in these sites, some of which were very abundant, as the Amazonian lineage Allobates crombiei, highlighting that most of the Tocantins state was poorly sampled. Substantial sampling gaps still remain through the State of Tocantins, and in order to reach a more accurate dimension of the state's amphibian diversity, these gaps must be overcome. Further taxonomic appraisals should be based on multiples lines of evidence (acoustic, molecular, and morphological data) and cover the entire distribution of these species, including the newly discovered populations presented here.

\section{Supplementary material}

The following online material is available for this article: Appendix 1

\section{Acknowledgements}

We would like to thank Dr. José P. Pombal Jr. and Dra. Manoela Woitovicz Cardoso for the access to amphibian collection housed in the Museu Nacional do Rio de Janeiro (MNRJ), Dr. Guarino Colli for access to amphibians housed at Coleção Herpetológica da Universidade de Brasília (CHUNB), Marcus Vinícios Moreira Barbosa for the access to amphibian collection housed in the Museu José Hidasi (MZJH), to Dr. Iracy Coelho de Menezes Martins and Antônio Avelino for the access of the amphibian collection housed in the Laboratório de Avaliação de Impactos Ambientais (LCIA) from the Universidade Federal do Tocantins. We thank ZUFMS by the accommodate the specimens collected during the field surveys. We also are grateful to Fazenda Dois Rios and Debora Rodello by the logistic support of samplings in the Lagoa da Confusão municipality. Thanks to Instituto Araguaia and Mrs. Juarez Sena Feitosa for the logistic for field samplings in Caseara municipality. We also thanks Neofauna Ambiental and its managers Hugo Buratti and Wlainer Silva by the logistical support during the field surveys in the Arraias municipality. To Roncadeira team, especially to its managers Maria Acirene Gomes Monteiro, Neusival Mendes, and Darlan Soares, for their help in logistic of field samplings in Taquaruçu district, Palmas municipality. 
Thiago Carvalho for indispensable support in the identification of species of the Adenomera and Pseudopaludicola genera, and the species from the Leptodactylus melanonotus species group. Ricardo Marques for the critical review. Vanessa Ferreira Gonçalves for help in the maps construction. LAS and EAP thanks the Conselho Nacional de Desenvolvimento Científico e Tecnológico (CNPq) by the scholarship (140408/2018-5 and 1417118/2016-1, respectively). LAS, RMF e PSC this study was financed in part by the Coordenação de Aperfeiçoamento de Pessoal de Nível Superior-Brasil (CAPES) - Finance Code 001. DJS thanks CNPq for his research fellowship (311492/2017-7). LAS and EAP thanks to the Instituto Chico Mendes de Conservação da Biodiversidade (ICMBio) for issuing a collecting permission (51036-5 and 54493-11, respectively).

Author Contributions

Leandro Alves da Silva: Significative contribution in conception and design of the study, data acquisition, analysis and interpretation of the data, and writing of the manuscript.

Priscila S. Carvalho: Significative contribution in analysis and interpretation of the data, and critical review adding intellectual content.

Elvis Almeida Pereira: Significative contribution in data acquisition, writing of the manuscript, and critical review adding intellectual content.

Renata Moleiro Fadel: Significative contribution in data acquisition, and critical review adding intellectual content.

Silionamã Pereira Dantas: Significative contribution in data acquisition.

Reuber Albuquerque Brandão: Significative contribution in data acquisition, analysis and interpretation of the data, and critical review adding intellectual content.

Diego José Santana: Significative contribution in conception and design of the study, analysis and interpretation of the data, critical review adding intellectual content.

\section{Conflicts of interest}

The authors declare that they have no conflict of interest related to the publication of this manuscript.

\section{References}

AB'SABER, A.N. 1977. Os domínios morfoclimáticos na América do Sul. Geomorfologia, 52:1-22.

AGOSTINHO, C.S., PELICICE F.M., MARQUES, E.E., SOARES, A.B. \& ALMEIDA, D.A.A. 2011. All that goes up must come down? Absence of downstream passage through a fish ladder in a large Amazonian river. Hydrobiologia, 675:1-12.

ALMEIDA, A.P., GASPARINI, J.L. \& PELOSO, P.L.V. 2011. Frogs of the state of Espírito Santo, southeastern Brazil: The need for looking at the 'coldspots'. Check List, 7:542-560.

ALMEIDA, J.P.F.A., NASCIMENTO, F.A.C., TORQUATO, S., LISBOA, B.S., TIBURCIO, I.C.S., PALMEIRA, C.N.S., LIMA, M.G. \& MOTT, T. 2016. Amphibians of Alagoas State, northeastern Brazil. Herpetol Notes, 9:123-140.

ALVARES, C.A., STAPE, J.L., SENTELHAS, P.C., DE MORAES, G., LEONARDO, J. \& SPAROVEK, G. 2013a. Köppen's climate classification map for Brazil. Meteorol Z, 22:711-728.

ALVARES, C.A., STAPE, J.L., SENTELHAS, P.C. \& GONÇALVES, J.L.M. 2013b: Modeling monthly mean air temperature for Brazil. Theor Appl Climatol, 113:407-427.
ANDRADE, F.L., MAGALHÃES, FM., NUNES-DE-ALMEIDA, C.H.L., VEIGAMENONCELLO, A.C.P., SANTANA, D.J., GARDA, A.A., LOEBMANN, D., RECCO-PIMENTEL, S.M., GIARETTA, A.A. \& TOLEDO, L.F. 2016. A new species of long-legged Pseudopaludicola from northeastern Brazil (Anura, Leptodactylidae, Leiuperinae). Salamandra, 52:107-124.

ANDRADE, F.S., HAGA, I.A., BANG, D.L. \& GIARETTA, A.A. 2017. The differential acoustic diagnosis between two Pseudopaludicola sister species (Anura, Leptodactylidae, Leiuperinae). Zootaxa, 4319:391-400.

ANDRADE, F.S., SILVA, L.A., KOROIVA, R., FADEL, R.M. \& SANTANA, D.J. 2019. A new species of Pseudopaludicola Miranda-Ribeiro, 1926 (Anura: Leptodactylidae: Leiuperinae) from an Amazonia-Cerrado transitional zone, state of Tocantins, Brazil. J Herpetol, 53:68-80.

ANDRADE, S.P., ROCHA, C.F., \& VAZ-SILVA, W. 2018. The advertisement call of Proceratophrys branti Brandão, Caramaschi, Vaz-Silva \& Campos, 2013 (Amphibia, Anura, Odontophrynidae). Zootaxa, 4379:445-447.

ANDRADE, S.P. \& VAZ-SILVA, W. 2012. First state record and distribution extension of Pleurodema diplolister (Peters 1870) (Anura: Leiuperidae) from state of Goiás, Brazil. Check List, 8:149-151.

ARAÚJO, E.L., CASTRO, C.C. \& ALBUQUERQUE, U.P. 2007. Dynamics of Brazilian Caatinga - A Review Concerning the Plants, Environment and People. Functional Ecosystems and Communities, 1:15-28.

AULER, A.S., WANG, X., EDWARDS, R.L., CHENG, H., CRISTALLI, P.S., SMART, P.L. \& RICHARDS, D.A. 2004. Quaternary ecological and geomorphic changes associated with rainfall events in presently semi-arid northeastern Brazil. J Quartenary Sci, 19:693-701.

AZEVEDO, J.A.R.; VALDUJO, P.H. \& NOGUEIRA, C.C. 2016. Biogeography of anurans and squamates in the Cerrado hotspot: coincident endemism patterns in the richest and most impacted savanna on the globe. J Biogeogr, 43:2454-2464.

AZEVEDO-RAMOS, C., LA MARCA, E., COLOMA, L.A. \& RON, S. 2010. Hypsiboas cinerascens. The IUCN Red List of Threatened Species 2010:e. T55494A11309180. http://dx.doi.org/10.2305/IUCN.UK.2010-2.RLTS T55494A11309180.en. Downloaded on 24 July 2018.

BAKER, P.A. \& FRITZ, S.C. 2015. Nature and causes of Quaternary climate variation of tropical South America. Quaternary Sci Rev, 124:31-47.

BICKFORD, D., LOHMAN, D.J., SODHI, N.S., NG, P.K.L., MEIER, R., WINKER, K., INGRAM, K.K. \& DAS, I. 2006. Cryptic species as a window on diversity and conservation. Trends Ecol Evol, 22:147-155.

BINI, L.M., DINIZ-FILHO, J.A.F., RANGEL, T.F.L.V.B., BASTOS, R.P. \& PINTO, M.P. 2006. Challenging Wallacean and Linnean shortfalls: knowledge gradients and conservation planning in a biodiversity hotspot. Divers Distrib, 12:475-482.

BRANDÃO, R.A. \& ARAÚJO, A.F.B. 2008. Changes in Anuran Species Richness and Abundance Resulting from Hydroelectric Dam Flooding in Central Brazil. Biotropica, 40:263-266.

BRANDÃO, R.A. \& PERES JUNIOR, A.K. 2001. Levantamento da Herpetofauna na área de influência do Aproveitamento Hidroelétrico da UHE Luís Eduardo Magalhães, Palmas, TO. Humanitas, 3:35-50.

BRANDÃO, R.A., CARAMASCHI, U., VAZ-SILVA, W. \& CAMPOS, L.A. 2013. Three new species of Proceratophrys Miranda-Ribeiro 1920 from Brazilian Cerrado (Anura, Odontophrynidae). Zootaxa, 3750:321-347.

BRANDÃO, R.A., MACIEL, S. \& ÁLVARES, G.F.R. 2016. Guia dos Anfíbios do Distrito Federal, Brasil. http:// www.lafuc.com (accessed at 07/07/2019).

BRASILEIRO, C.A., LUCAS, E.M., OYAMAGUCHI, H.M., THOMÉ, M.T.C. \& DIXO, M. 2008. Anurans, Northern Tocantins River Basin, states of Tocantins and Maranhão, Brazil. Check List, 4:185-197.

BRUSCHI, D.P., BUSIN, C.S., TOLEDO, L.F., VADCONCELLOS, G.A., STRUSMANN, C., WEBER, L.N., LIMA, A.P., LIMA, J.D. \& RECCO-PIMENTEL, S.M. 2013. Evaluation of the taxonomic status of populations assigned to Phyllomedusa hypochondrialis (Anura, Hylidae, Phyllomedusinae) based on molecular, chromosomal, and morphological approach. Biomed Central Genetics, 14:1-14. 
BRUSQUETTI, F., JANSEN, M., BARRIO-AMORÓS, C., SEGALLA, M. \& HADDAD, C.F.B. 2014. Taxonomic review of Scinax fuscomarginatus (Lutz, 1925) and related species (Anura; Hylidae). Zool J Linn Soc-Lond, 171:783-821.

CAMINER, M. A. \& RON, S. R. 2014. Systematics of treefrogs of the Hypsiboas calcaratus and Hypsiboas fasciatus species complex (Anura, Hylidae) with the description of four new species. ZooKeys, 370:1-68.

CARAMASCHI, U. 2006. Redefinição do grupo de Phyllomedusa hypochondrialis, com redescrição de $P$. megacephala (Miranda-Ribeiro, 1926), revalidação de $P$. azurea Cope, 1862 e descrição de uma nova espécie (Amphibia, Anura, Hylidae). Arquivos do Museu Nacional, 64:159-179.

CARAMASCHI, U. 2010. Notes on the taxonomic status of Elachistocleis ovalis (Schneider, 1799) and description of five new species of Elachistocleis Parker, 1927 (Amphibia, Anura, Microhylidae). Boletim do Museu Nacional, 527:1-30.

CARNAVAL, A. C. \& BATES, J. M. 2007. Amphibian DNA shows marked genetic structure and tracks Pleistocene climate change in northeastern Brazil. Evolution, 61:2942-2957.

CARVALHO, T. R., MARTINS, L. B.; TEIXEIRA, B. F. V.; GODINHO L. B. \& GIARETTA, A. A. 2015a. Intraspecific variation in acoustic traits and body size, and new distributional records for Pseudopaludicola giarettai Carvalho, 2012. (Anura, Leptodactylidae, Leiuperinae): implications for its congeneric diagnosis. Pap Avulsos de Zool, 55:245-254.

CARVALHO, T.R. \& GIARETTA, A.A. 2013a. Bioacoustics reveals two new syntopic species of Adenomera Steindachner (Anura: Leptodactylidae: Leptodactylinae) in the Cerrado of central Brazil. Zootaxa, 3731:533-551.

CARVALHO, T.R. \& GIARETTA, A.A. 2013b. Taxonomic circumscription of Adenomera martinezi (Bokermann, 1956) (Anura: Leptodactylidae: Leptodactylinae) with the recognition of a new cryptic taxon through a bioacoustic approach. Zootaxa, 3701:207-237.

CARVALHO, T.R., GIARETTA, A.A., ANGULO, A., HADDAD, C.F. \& PELOSO, P.L. 2019. A new Amazonian species of Adenomera (Anura: Leptodactylidae) from the Brazilian state of Pará: a tody-tyrant voice in a frog. American Museum Novitates, 3919:1-22.

CARVALHO, T.R., GIARETTA, A.A., TEIXEIRA, B.F.V. \& MARTINS L.B. 2013. New bioacoustic and distributional data on Bokermannohyla sapiranga Brandão et al. 2012. (Anura: Hylidae): revisiting its diagnosis in comparison with B. pseudopseudis (Miranda-Ribeiro, 1937). Zootaxa, 3746:383-392.

CARVALHO, T.R., MARTINS, L.B., \& GIARETTA, A.A. 2016. A new account for the endangered Cerrado Rocket Frog Allobates goianus (Bokermann, 1975) (Anura: Aromobatidae), with comments on taxonomy and conservation. Acta Herpetol, 11:21-30.

CARVALHO, T.R., TEIXEIRA, B.F.V., MARTINS, L.B. \& GIARETTA, A.A. 2015b. Intraspecific variation and new distributional records for Pseudopaludicola species (Anura, Leptodactylidae, Leiuperinae) with trilled advertisement call pattern: diagnostic characters revisited and taxonomic implications. North-West J Zool, 11:262-273.

CASTROVIEJO-FISHER, S., GUAYASAMIN, J.M., GONZALES-VOYER, A. \& VILÀ, C. 2014. Neotropical diversification seen through glassfrogs. J Biogeogr, 41:66-80.

CASTROVIEJO-FISHER, S., VILÀ, C., AYARZAGUENA, J., BLANC, M. \& ERNEST, R. 2011. Species diversity of Hyalinobatrachium glassfrogs (Amphibia: Centrolenidae) from the Guiana Shield, with the description of two new species. Zootaxa, 3132:1-55.

CEI, J.M. 1970. Relaciones serologicas entre los Leptodactylus del grupo ocellatus-chaquensis de la Cuenca Chaco Paranaense y la forma macrosternum. Acta Zool Lilloana, 27:299-306.

CFBIO n 148/2012. "Regulamenta os procedimentos de captura, contenção, marcação e coleta de animais vertebrados previstos nos Artigos, $4^{\circ}, 5^{\circ}, 6^{\circ}$ e $8^{\circ}$ da Resolução CFBio no $301 / 2012$.

CINTRA, C.D.E., SILVA, H.L.R. \& JUNIOR, NJ. S. 2013. New state record of Vitreorana eurygnatha (Lutz 1925) (Anura: Centrolenidae) in Brazil. Herpetol Notes, 6:587-590.
COLLI, G.R., BASTOS, R.P. \& ARAÚJO, A.F.B. 2002. The character and dynamics of the Cerrado Herpetofauna. In: The Cerrados of Brazil: Ecology and Natural History of a Neotropical Savanna (P.S. Oliveira \& R.J. Marquis, ed.). Columbia University Press, New York, p.223-241.

DAYRELL, J.S., FERNANDES, V.D., MOURA, M.R. \& FEIO, R.N. 2012 New records of Trachycephalus mambaiensis (Amphibia: Hylidae) from a cerrado region in Minas Gerais state, Brazil. Check List, 8: 269-271.

DE SÁ, R.O., GRANT, T., CAMARGO, A., HEYER, W.R., PONSSA, M.L. \& STANLEY, E. 2014. Systematics of the Neotropical genus Leptodactylus Fitzinger, 1826 (Anura: Leptodactylidae): Phylogeny, the relevance of non-molecular evidence, and species accounts. S Am J Herpetol, 9:1-128.

DE SÁ, R.O., TONINI, J.F.R., VAN HUSS, H., LONG, A., CUDDY, T., FORLANI, M. C., PELOSO, P. L. V., ZAHER, H. \& C. F. B. HADDAD. 2019. Multiple connections between Amazonia and Atlantic Forest shaped the phylogenetic and morphological diversity of Chiasmocleis Mehely, 1904 (Anura: Microhylidae: Gastrophryninae). Mol Phylogenet Evol, 130:198-210

DINIZ-FILHO, J.A.F., BASTOS, R.P., RANGEL, T.F.L.V.B., BINI, L.M., CARVALHO, P.P. \& SILVA, R.J. 2005. Macroecological correlates and spatial patterns of anuran description dates in the Brazilian Cerrado. Globral Ecol Biogeogr, 14:469-477.

DINIZ-FILHO, J.A.F., BINI, L.M., PINTO, M.P., RANGEL, T F.L.V.B., CARVALHO, P., VIEIRA, S.L. \& BASTOS, R.P. 2007. Conservation biogeography of anurans in Brazilian Cerrado. Biodivers Conserv, 16:997-1008.

DINIZ-FILHO, J.A.F., BINI, L.M., PINTO, M.P., RANGEL, T.F.L.V.B., CARVALHO, P. \& BASTOS, R.P. 2006. Anuran species richness, complementarity and conservation conflicts in Brazilian Cerrado. Acta Oecol, 29:9-15.

DUELLMAN, W.E. \& HOOGMOED, M.S. 1992. Some hylid frogs from the Guiana Highlands, northeastern South America: new species, distributional records, and a generic reallocation. Occasional Papers of the Museum of Natural History, the Univ. of Kansas, Lawrence, Kans. Forgotten Books, 28p.

FAIVOVICH, J., HADDAD, C.F.B., GARCIA, P.C.A., FROST, D.R., CAMPBELL, J.A. \& WHEELER, W.C. 2005. Systematic review of the frog family Hylidae, with special reference to Hylinae: Phylogenetic analysis and taxonomic revision. B Am Mus Nat Hist, 294:1-240.

FEARNSIDE, P. M. 2009. As hidrelétricas de Belo Monte e Altamira (Babaquara) como fontes de gases de efeito estufa. Novos Cadernos NAEA, 12:5-56.

FOUQUET, A., MARTINEZ, Q., ZEIDLER, L., COURTOIS, E.A., GAUCHER, P., BLANC, M., LIMA, J.D., SOUZA, S.M.; RODRIGUES, M.T. \& KOK, P.J.R. 2016. Cryptic diversity in the Hypsiboas semilineatus species group (Amphibia, Anura) with the description of a new species from the eastern Guiana Shield. Zootaxa, 4084:79-104.

FOUQUET, A., NOONAN, B.P., RODRIGUES, M.T., PECH, N., GILLES, A. \& GEMMELL, N.J. 2012. Multiple Quaternary Refugia in the Eastern Guiana Shield Revealed by Comparative Phylogeography of 12 Frog Species. Syst Biol, 61:461-489.

FRANÇOSO, R.D., BRANDÃO, R.A., NOGUEIRA, C.C., SALMONA, Y. B., MACHADO, R.B. \& COLLI, G. R. 2015. Habitat loss and the effectiveness of protected areas in the Cerrado Biodiversity Hotspot. Nat Conserv, 13:35-40

FREITAS M.A., LIMA T.O., FRANÇA D.P.F. 2011. Geographic distribution: Trachycephalus mambaiensis. Herpetol Rev, 42:387.

FROST, D.R. 2016. Amphibian Species of the World: an Online Reference. Version 6.0 (January 18, 2016). Electronic Database accessible at http:// research.amnh.org/herpetology/amphibia/index.html. American Museum of Natural History, New York, USA.

FROST, D.R. 2019. Amphibian Species of the World: an Online Reference. Version 6.0 (May 03, 2019). Electronic Database accessible at http:// research.amnh.org/herpetology/amphibia/index.html. American Museum of Natural History, New York, USA. 
FUNK, W.C., CAMINER, M., \& RON, S.R. 2011. High levels of cryptic species diversity uncovered in Amazonian frogs. P Roy Soc B-Biol Sci, 279:1806-1814.

GALLANT, A.L., KLAVER, R.W., CASPER, G.S. \& MICHAEL, J.L. 2007. Global rates of habitat loss and implications for amphibian conservation. Copeia, 2007:967-979.

GARDA, A.A., BIAVATI, G.M. \& COSTA, G.C. 2006. Sexual dimorphism, female fertility, and diet of Pipa arrabali (Anura, Pipidae) in Serra do Cachimbo, Pará, Brazil. S Am J Herpetol, 1:20-24.

GASCON, C. 1992. Spatial distribution of Osteocephalus taurinus and Pipa arrabali in a central Amazonian forest. Copeia, 1992:894-897.

GEHARA, M., CRAWFORD, A.J., ORRICO, V.G.D., RODRÍGUEZ, A., LOTTERS, S., FOUQUET, A., BARRIENTOS, L.S., BRUSQUETTI, F., DE LA RIVA, I., ERNST, R., URRUTIA, G. G., GLAW, F., GUAYASAMIN, J.M., HOLTING, M., JANSEN, M., KOK, P.J.R., KWET, A., LINGNAU, R., LYRA, M., MORAVEC, J., POMBAL JR., J.P., ROJAS-RUNJAIC, F.J.M., SCHULZE, A., CELSASEÑARIS, J., SOLÉ, M., RODRIGUES, M.T., TWOMEY, E., HADDAD, C.F.B., VENCES, M. \& KOHLER, J. 2014. High levels of diversity uncovered in a widespread nominal taxon: continental phylogeography of the neotropical tree frog Dendropsophus minutus. Plos One, 9:1-12.

GOIN, C.J. 1968 “1967”. A new centrolenid frog from Guyana. Quarterly Journal of the Florida Academy of Sciences, 30:115-118.

GRAY, J.E. 1825. A synopsis of the genera of reptiles and Amphibia, with a description of some new species. Annals of Philosophy. Series 2. London, 10:193-217.

GREENPEACE, 2016. Damming the Amazon: Amazon the risky business of hydropower in the Amazon. Greenpeace Brasil, São Paulo.

GUAYASAMIN, J.M., CASTROVIEJO-FISHER, S., TRUEB, L., AYARZAGUENA, J., RADA, M. \& VILÀ, C. 2009. Phylogenetic systematics of Glassfrogs (Amphibia: Centrolenidae) and their sister taxon Allophryne ruthveni. Zootaxa, 2100:1-97.

HABERLE, S. G. \& MASLIN, M. A. 1999. Late Quaternary Vegetation and Climate Change in the Amazon Basin Based on a 50,000 Year Pollen Record from the Amazon Fan, ODP Site 932. Quaternary Res, 51:27-38.

HAGA I.A., ANDRADE F.S., BRUSCHI, D.P., RECCO-PIMENTEL S.M. \& GIARETTA A.A. 2017. Unrevealing the leaf frogs Cerrado diversity: A new species of Pithecopus (Anura, Arboranae, Phyllomedusidae) from the Mato Grosso state, Brazil. Plos One, 12:e184631.

HEDGES, S.B., DUELLMAN, W.E. \& HEINICKE, M.P. 2008. New World direct-developing frogs (Anura: Terrarana): Molecular phylogeny, classification, biogeography, and conservation. Zootaxa, 1737:1-182.

HEINICKE, M.P., DUELLMAN, W.E., TRUEB, L., MEANS, D.B., MACCULLOCH, R.D. \& HEDGES, S.B. 2009. A new frog family (Anura: Terrarana) from South America and an expanded direct-developing clade revealed by molecular phylogeny. Zootaxa, 2211:1-35.

HEYER, W. R. 2014. Morphological analyses of frogs of the Leptodactylus latrans complex (Amphibia, Leptodactylidae) from selected localities in South America. P Biol Soc Wash, 126:369-378.

HOFFMANN, M. 2010. The impact of conservation on the status of the world's vertebrates. Science, v.330, n.6010, p.1503-1509. doi: 10.1126/ science.1194442.

HOOGMOED, M.S. 1990. Resurrection of Hyla wavrini Parker (Amphibia: Anura: Hylidae), a gladiator frog from northern South America. Zool Meded, 64:71-93.

HOORN, C., WESSELINGH, F.P., TER STEEGE, H., BERMUDEZ, M.A., MORA, A., SEVINK, J., SANNMARTÍN, I., SANCHEZ-MESEGUER, A., ANDERSON, C.L., FIGUEIREDO, J.P., JARAMILLO, C., RIFF, D., NEGRI, F.R., HOOGHIEMSTRA, H., LUNDBERG, J., STADLER, T., SARKINEN, T. \& ANTONELLI, A. 2010. Amazonia Through Time: Andean Uplift, Climate Change, Landscape Evolution, and Biodiversity. Science, 330:927-931.

IBGE, 2014. Estimativas populacionais para os municípios brasileiros. http:// www.ibge.gov.br/home/estatistica/populacao/estimativa2014/estimativa dou.shtm (último acesso em: 18/Jan/2016).
LA MARCA, E., AZEVEDO-RAMOS, C., COLOMA, L.A., RON, S. \& HARDY, J. 2010. Sphaenorhynchus lacteus. The IUCN Red List of Threatened Species 2010: e.T56015A11409132. http://dx.doi.org/10.2305/ IUCN.UK.2010-2.RLTS.T56015A11409132.en. (último acesso em: 24/ jul/2018)

LIMA, A.P., ERDTMANN, L.K. \& AMÉZQUITA, A. 2012. Advertisement call and colour in life of Allobates crombiei (Morales) "2000" [2002] (Anura: Aromobatidae) from the type Locality (Cachoeira do Espelho), Xingu River, Brazil. Zootaxa, 3475:86-88.

LIMA, J.R., GALATTI, U., LIMA, C.J., FÁVERI, S.B., VASCONCELOS, H.L. \& NECKEL-OLIVEIRA, S. 2015. Amphibians on Amazonian Land-Bridge Islands are Affected More by Area Than Isolation. Biotropica, 47:369-376.

LOURENÇO, L.B., TARGUETA, C.P., BALDO, D., NASCIMENTO, J., GARCIA, P.C.A., ANDRADE, G.V., HADDAD, C.F.B. \& RECCOPIMENTEL, S.M. 2015. Phylogeny of frogs from the genus Physalaemus (Anura, Leptodactylidae) inferred from mitochondrial and nuclear gene sequences. Mol Phylogenet Evol, 92:204-216.

MARTINS, L.B. \& GIARETTA, A.A. 2013. Morphological and acoustic characterization of Proceratophrys goyana (Lissamphibia: Anura: Odontophrynidae), with the description of a sympatric and related new species. Zootaxa, 3750:301-320.

MÂNGIA, S., KOROIVA, R., NUNES, P.M.S., ROBERTO, I.J., ÁVILA, R.W., SANT'ANNA, A.C., SANTANA, D.J. \& GARDA, A.A. 2018. A new species of Proceratophrys (Amphibia: Anura: Odontophrynidae) from the Araripe Plateau, Ceará State, northeastern Brazil. Herpetologica 74:255-268.

MCCALLUM, M.L. 2015. Vertebrate biodiversity losses point to a sixth mass extinction. Biodivers Conserv, 24:2497-2519.

MÜLLER, L. 1924. Neue laubfrösche aus dem Staate Santa Catharina, S.O. Brasilien. Zoologischer Anzeiger 59:233-238.

NATURATINS, 2017. http://gesto.to.gov.br/uc/. (último acesso em: 15/jan/2017)

NUNES, I., SUÁREZ, P., GORDO, M. \& POMBAL JR, J.P. 2013. A second species of Trachycephalus Tschudi (Anura: Hylidae) with a single vocal sac from the Brazilian Amazon. Copeia, 4:634-640.

NUNES-DE-ALMEIDA, C.H.L. \& TOLEDO, L.F. 2012. A new species of Elachistocleis Parker (Anura, Microhylidae) from the State of Acre, Northern Brazil. Zootaxa, 3424:43-50.

OLIVEIRA, J.S.P., DE FREITAS, E.B., DE LIMA, C.A., PIRES, R.A.P. \& DE-CARVALHO. C.B. 2018. Geographic distribution: Adenomera cotuba. Herpetol. Review, 49:69.

OLIVEIRA-FILHO, A.T. \& RATTER, J.A. 2002. Vegetation Physiognomies and woody flora of the Cerrado Biome. In: The Cerrados of Brazil: Ecology and Natural History of a Neotropical Savanna (P.S. Oliveira \& R.J. Marquis ed.). Columbia University Press, New York, p.90-120.

ORRICO V.G.D., NUNES I., MATTEDI C., FOUQUET A., LEMOS A.W., RIVERA-CORREA M., LYRA M.L., LOEBMANN D., PIMENTA B.V.S., CARAMASCHI U., RODRIGUES M.T. \& HADDAD, C.F.B. 2017. Integrative taxonomy supports the existence of two distinct species within Hypsiboas crepitans (Anura: Hylidae). Salamandra, 53:99-113.

PADIAL, J.M., GRANT, T. \& FROST, D.R. 2014. Molecular systematics of terraranas (Anura: Brachycephaloidea) with an assessment of the effects of alignment and optimality criteria. Zootaxa, 3825:1-132.

PADIAL, J.M., MIRALLES, A., DE LA RIVA, I. \& VENCES, M. 2010. The review integrative future of taxonomy. Front Zoo, 7:1-14.

PAVAN, D. \& DIXO, M. 2004. A Herpetofauna da área de influência do reservatório da Usina Hidrelétrica Luís Eduardo Magalhães, Palmas, TO. Humanitas, 4:13-30.

PAVAN, D. 2007. Assembléias de anfíbios e répteis ao longo da bacia do Rio Tocantins e o impacto do aproveitamento hidrelétrico da região em sua conservação. Tese de doutorado. Universidade de São Paulo, São Paulo.

PAZ, A., SPANOS, Z., BROWN, J.L., LYRA, M., HADDAD, C., RODRIGUES, M. \& CARNAVAL, A. 2019. Phylogeography of Atlantic Forest glassfrogs (Vitreorana): when geography, climate dynamics and rivers matter. Heredity, 122:545-557. 
PELICICE, F.M., POMPEU, O.S. \& AGOSTINHO, A.A. 2014. Large reservoirs as ecological barriers to downstream movements of Neotropical migratory fish. Fish Fish, 16:1-19.

PELOSO P.L.V., OLIVEIRA R.M., STURARO M.J., RODRIGUES M.T., LIMA-FILHO G.R., BITAR Y. O.C., WHEELER W.C. \& ALEIXO A. 2018. Phylogeny of map tree frogs, Boana semilineata species group, with a new Amazonian species (Anura: Hylidae). S Am J Herpetol, 13:150-169.

ROBERTO, I.J. \& LOEBMANN, D. 2016. Composition, distribution patterns, and conservation priority areas for the herpetofauna of the state of Ceará, northeastern Brazil. Salamandra, 52:134-152.

ROBERTO, I.J., RIBEIRO, S.C. \& LOEBMANN, D. 2013. Amphibians of the state of Piauí, Northeastern Brazil: a preliminary assessment. Biota Neotropica, 13:322-330.

ROCHA, G.F., FERREIRA, L.G., FERREIRA, N.C. \& FERREIRA, M.E. 2011. Detecção de desmatamentos no bioma Cerrado entre 2002 e 2009: Padrões, tendências e impactos. Revista Brasileira de Cartografia, 63:341-349.

RODRIGUES, D.J., NORONHA, J.C., LIMA, M.M., BARROS, A.B., FARIA, A.N. \& ALMEIDA, E.J. 2015. Herpetofauna. In: Biodiversidade do Parque Estadual Cristalino (D.J. Rodrigues, J.C. Noronha, V.F. Vindica, F.R. Barbosa, ed.). Áttema Editorial, Sinop, Mato Grosso, p. 207-224.

ROSSA-FERES, D.C. SAWAYA R.J., FAIVOVICH, J., GIOVANELLE, J.G.R., BRASILEIRO, C.A., SCHIESARI, L., ALEXANDRINO, J. \& HADDAD, C.F.B. 2011. Anfíbios do Estado de São Paulo, Brasil: conhecimento atual e perspectivas. Biota Neotropica, 11:1-19.

SANO, E.E., ROSA, R., BRITO, J.L.S. \& FERREIRA, L.G. 2010. Land cover mapping of the tropical savanna region in Brazil. Environ Monit Assess, 166:113-124.

SANTANA, D.J., BARROS, A.B., PONTES, R. \& FEIO, R.N. 2015. A new species of glassfrog genus Vitreorana (Anura, Centrolenidae) from the Cerrado Domain, Southeastern Brazil. Herpetologica, 71:289-298.

SANTORO, G.R.C.C. \& BRANDAO, R.A. 2014. Reproductive modes, habitat use and richness of anurans from Chapada dos Veadeiros region, Goiás, Brazil. North-West J Zool, 10:365-373.

SANTOS, M.A.S., CUNHA, S.J.T., SANTOS, J.S.B. \& SANTANA, A.C. 2007. Mercado e dinâmica local da cadeia produtiva da pecuária de corte na Região Norte. Banco da Amazônia, Belém. 2007, p. 1-48.

SEGALLA, M.V., CARAMASCHI, U., CRUZ, C.A.G., GARCIA, P.C.A., GRANT, T., HADDAD, C.F.B., SANTANA, D.J., TOLEDO, L.F. \& LANGONE, J.A. 2019. Brazilian Amphibians: List of Species. Herpetologia Brasileira, 8:65-96.

SILVA, L.A, DANTAS, S.P., SANTOS, D.L., NETO, H.B. \& SANTANA, D.J. 2018. Newly distribution of Rhinella gildae Vaz-Silva et al., 2015 (Anura, Bufonidae): a little-known species of the Rhinella margaritifera species group. Herpetol Notes, 11:121-125.

SILVA, L.A.; HOFFMANN, M.C. \& SANTANA, D.J. 2014. New record of Corythomantis greeningi Boulenger, 1896 (Amphibia, Hylidae) in the Cerrado domain, state of Tocantins, Central Brazil. Herpetol Notes, 7:717-720.

SILVANO, D.L. \& SEGALLA, M.V. 2005. Conservation of Brazilian Amphibians. Conserv. Biol, 19:653-658.

SILVANO, D.L., VALDUJO, P.H., COLLI, G.R. 2016. Priorities for Conservation of the Evolutionary History of Amphibians in the Cerrado. In: Pellens R. \& Grandcolas, P. (Org.). Biodiversity Conservation and Phylogenetic Systematics: Preserving our Evolutionary Heritage in an Extinction Crisis. 1ed.Cham: Springer International Publishing, 2016, v. 14, p. 1-18.

SILVEIRA, A.L. \& PACHECO, A.S. 2011. Um novo registro de Trachycephalus mambaiensis (Amphibia, Anura, Hylidae), no Estado de Minas Gerais, Brasil. Biotemas, 24:141-143.
SILVEIRA, L.F., BEISIEGE, B.M., CURCIO, F.F., VALDUJO, P.H., DIXO, M., VERDADE, V.K., MATTOX, G.M.T. \& CUNNINGHAM, P.T.M. 2010. What use do fauna inventories serve? Estudos Avançados, 24:173-207.

SOUSA, B.L. \& BERNARDE, P.S. 2007. Geographic distribution: Pipa arrabali (Arrabal's Surinam Toad). Herpetological Review, 38:98-98.

TOCANTINS 2015. Palmas, Tocantins, Brazil: Governo do Tocantins (June 11, 2019). Electronic Database accessible at https://web.archive.org/ web/20151101133407/http://portal.to.gov.br/tocantins/2.

TOLEDO, L.F. LOEBMANN, D. \& HADDAD, C.F.B. 2010. Revalidation and redescription of Elachistocleis cesarii (Miranda-Ribeiro, 1920) (Anura: Microhylidae). Zootaxa, 2418:50-60.

TOLEDO, L.F., BECKER, G., HADDAD, C.F.B. \& ZAMUDIO, K.R. 2014 Rarity as an indicator of endangerment in neotropical frogs. Biol Conserv, 179:54-62.

TRUEB, L. \& CANNATELLA, D.C. 1986. Systematics, morphology, and phylogeny of genus Pipa (Anura: Pipidae). Herpetologica, 42:412-449.

UFT, 2018. Catálogo das condições de oferta dos cursos de graduação da UFT. https://ww2.uft.edu.br/index.php/ensino (accessed at 08/09/2019).

VALDUJO, P.H., CAMACHO, A., RECORDER, R.S., JUNIOR, M.T., GHELLERE, J.M.B., MOTT, T., NUNES, P.M.S., NOGUEIRA, C. \& RODRIGUES, M.T. 2011. Amphibians from Estação Ecológica Serra Geral do Tocantins, Jalapão region, Tocantins and Bahia States. Biota Neotropica, $11: 251-264$

VALDUJO, P.H., SILVANO, D.L., COLLI, G. \& MARTINS, M. 2012 Anuran species composition and distribution patterns in Brazilian Cerrado, a Neotropical hotspot. S Am J Herpetol, 7:63-78.

VAZ-SILVA, W. \& ANDRADE, T. A. 2009. (Amphibia: Anura: Pipidae) Pipa pipa: Distribution extension, new state record and geographic distribution map. Check List, 5:507-509.

VEIGA-MENONCELLO, A.C.P., LOURENÇO, L.B., STRÜSSMANN, C., ROSSA-FERES, D.C., ANDRADE, G.V., GIARETTA, A.A. \& RECCOPIMENTEL, S.M. 2014. A phylogenetic analysis of Pseudopaludicola (Anura) providing evidence of progressive chromosome reduction. Zool Scr, 43:261-272.

VITOUSEK, P.M., MOONEY, H.A., LUBCHENCO, J. \& MELILLO, J.M. 1997. Human domination of Earth's Ecosystems. Science, 277:494-499.

VITT, L.J., CALDWELL, J.P., COLLI, G.R., GARDA, A.A., MESQUITA, D.O., FRANÇA, F.G.R., SHEPARD, D.B., COSTA, G.C., VASCONCELLOS, M.M. \& NOVAES-E-SILVA, V. 2005. Uma atualização do guia fotográfico de répteis e anfíbios da região do Jalapão no Cerrado Brasileiro. Occas. Pap./ Sam Noble Oklahoma Museum of Natural History, 2:1-24.

WERNECK, F.P. 2011. The diversification of eastern South American open vegetation biomes: Historical biogeography and perspectives. Quaternary Sci. Rev., 30:1630-1648.

WERNECK, F.P., COSTA, G.C., COLLI, G.R., PRADO, D.E. \& SITES JR., J.W. 2011. Revisiting the historical distribution of Seasonally Dry Tropical Forests: New insights based on paleodistribution modelling and palynological evidence. Global Ecol Biogeogr., 20:272-288.

WERNECK, F.P., NOGUEIRA, C., COLLI, G.R., SITES JR., J.W. \& COSTA, G.C. 2012. Climatic stability in the Brazilian Cerrado: implications for biogeographical connections of South American savannas, species richness and conservation in a biodiversity hotspot. J Biogeogr., 39:1695-1706.

Received: $31 / 07 / 2019$

Revised: 11/10/2019

Accepted: 07/11/2019

Published online: 27/01/2020 